\title{
脳性麻㾇の機能予後
}

座長/君塚葵・北原佶

\section{新生児期の早期診断よりみた脳性麻 痺の機能予後}

長崎市障害福祉センター

䅖山富太郎

長崎大学医学部附属病院理学療法部

大城 昌平

\section{はじめに}

ハイリスク新生児に対して出生早期に予後診断 を行うことは, 発達障害の予防, 発達促進, 育児 支援を図るうえで大切である，脳性麻痺そのもの を治癒させることはできないが, 新生児期での告 知と早期療育のための介入は, その後の医学的り ハビリテーション（以下，リハ）に加え, とくに 脳性麻痺児, 者の社会性獲得に向けた社会リ八推 進の視点からも重要となる.

新生児期での評価, 診断法としては, 画像診断 に加えて, Dubowitz 法1)などの姿勢緊張, 反 射・反応の検査を主体とした神経学的検査, Precht1 ${ }^{2)}$ による自発運動の分析 (general movements: GMs), Brazelton 新生児行動評価 ${ }^{3)}$ (neonatal behavioral assessment scale: NBAS) による行動学的評価 (Prechtl \& Beintemaによる神経学的評価も含まれている) がある.NBAS は新生児の評価と同時に，早期 介入にも応用できることから, (1) NBAS, (2) $\mathrm{GMs}$ の観察, (3)画像診断, の 3 者による総合的 評価を行っている.これらにより, 新生児期での
予測診断の確率が高まるため, 新生児期からの早 期介入・療育が可能となる ${ }^{4,5)}$.

\section{Brazelton 新生児行動評価（NBAS）}

NBAS は，新生児の行動システムを，(1)自律 神経系 (生理系), (2)状態系, (3)運動系, (4)注意/ 相互作用系の 4 つの行動系に分類して，それぞれ の行動系および行動系全体の組織化を評価するよ うになっている。スケールは, 35 項目の行動評 価項目 (補足項目を含む), 18 項目の神経学的評 価項目から構成される. 行動評価項目は 9 段階で 評価され，9段階の尺度は，それぞれの項目ごと に定義づけられている。神経学的評価項目は正常 反応, 反応なし, 低反応, 過唾反応, 非対称性の 5 つの尺度で評価される。

NBAS の評価は，ハイリスク成熟児では 40 , 42, 44 週の 3 回, 低出生体重児では修正胎齢 36 $\sim 38$ 週時（以下 NBAS 36），40４2 週時（以下 NBAS 40)，44〜46 週時（以下 NBAS 44）の 3 回行った.

NBAS の結果は, Lester のクラスター法6) よって, 評価項目を，1）慣れ反応，2）方位反 応，3）運動，4）状態の幅，5）状態調整，6）自 律神経の調整，7）補足項目，8）誘発反応，の8 つのクラスターに分類し，クラスターごとに点数 化（クラスター值）する.

NBAS クラスター値は, 誘発反応クラスター 值を除く他の行動クラスターでは, 得点が高いほ ど良い行動反応であることを示し, 誘発反応クラ スターは, 低い得点ほど異常反応が少ないことを 示す. 
NBAS は, 新生児行動の客観的な評価法とし て, ハイリスク新生児の経時的評価に利用でき る.

\section{NBAS による脳性麻痺児の行動特徵}

正常児では，新生児期に上述の 4 つの系の組織 化が進み，自己制御行動を発揮して環境との相互 作用をうまくはかることができ，順調に発達す る.

脳性麻痺の新生児期における行動特徴は, 新生 児行動の disorganization，ストレス反応の出現 などであり，新生児行動の回復が遅滞する.

ストレス徴候は環境への適応障害として, 自律 神経系, 運動系, 睡眠・覚醒状態系に反映され る。たとえば，注意力のある状態を維持すること は，未熟児やハイリスク児にとって負担のかかる ことである．注意力を集中しようとすることによ るストレスは他の系をみることにより推し測るこ とができる.

脳性麻痺児では環境刺激に対する高感受性が現 れやすい.一方，低感受性に見えることもある が，これは混乱した反応の表出をシャットダウン しているのかもしれないし，反応を起こせないほ ど重度な障害であるのかもしれない7)。新生児の 中枢神経系の可塑性を生かした機能回復に向け て，適切な環境設定や相互作用をはかることが重 要となる。目標は自己制御行動の支援であ る ${ }^{8 \sim 10)}$.

\section{2. 回復曲線}

\section{1）ハイリスク成熟児}

対象はハイリスク成熟児 43 例で, 新生児仮死 33 例, 頭蓋内出血 10 例, 後者のうち 7 例は仮死 を伴っていた. 3〜8 歳時の発達評価で, 正常 28 例, 歩行可能な軽〜中度脳性麻痺 5 例, 歩行不能 な重度脳性麻痺 10 例であった。

これら 3 群について, NBASクラスター值と 予後との関係を検討した. 正常群はすべてのクラ スターで回復が急速で，42 週には正常成熟児の 行動水準に達した。軽・中度脳性麻痺群は正常群 に比べて方位反応, 運動, 誘発反応, 補助項目の クラスターで回復が遅れ, 重度脳性麻痺群はすべ てのクラスターで回復が遅延した.

44 週児の NBAS クラスター值と予後との統計 学的検討は, 正常群と軽・中度脳性麻痺群間の比 較において方位反応, 運動, 誘発反応, 補足項目 のクラスターで有意差がみられ，正常群と重度脳 性麻痺群の間では全てのクラスターで有意差がみ られた。図 1 は 3 群の運動クラスターと誘発反応 クラスターの回復曲線を示す。

\section{2) 低体重出生児}

対象は低出生体重児 209 例で，5～6 歳時の発 達評価は, 正常発達 148 例（以下，正常群)，脳 性麻痺 17 例 (以下, CP 群), 精紳運動発達遅帯 児 44 例（以下，MR 群）であった。

$\mathrm{CP}$ 群の回復曲線は方位反応, 運動, 状態調 整, 誘発反応, 補足項目のクラスターで正常群に

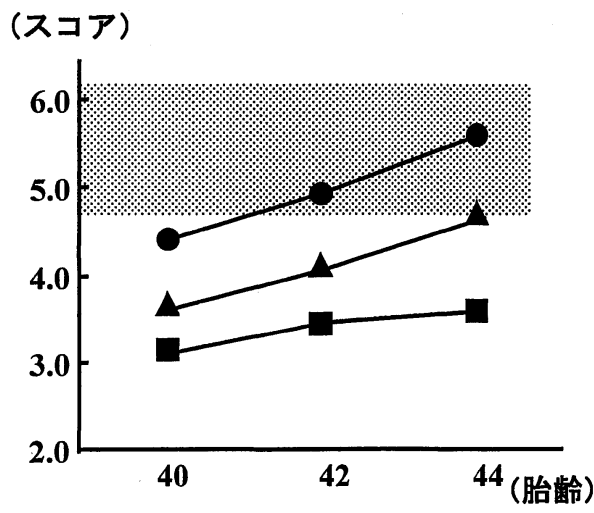

\section{(スコア)}

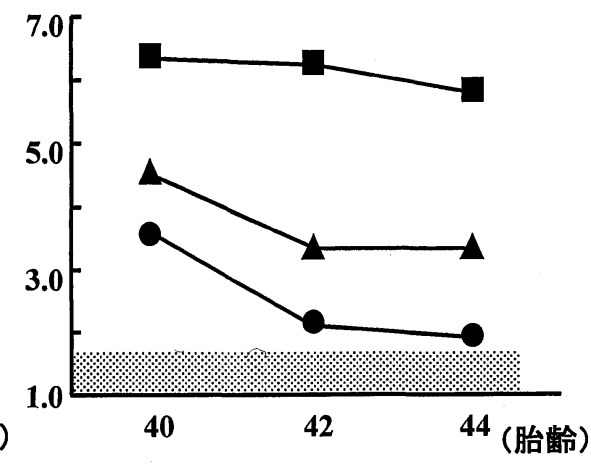

図 1 ハイリスク成熟児の運動(左) と誘発反応(右)クラスターの回復曲線 ○は正常発達, \は軽・中度障害, 口は重度障害, —は正常成熟児の発達範囲を示す. 
比べて回復が遅延し, MR 群では方位反応, 運 動, 状態の幅, 補足項目クラスターの回復がそし かった. CP 群と MR 群間では状態の幅と誘発反 応クラスターで差異が大きかった（状態の幅では $\mathrm{CP}$ 群が高值, 誘発反応では MR 群が低值). 方 位反応クラスター值は CP 群が MR 群よりも高 值を示したが，両者間に有意差はなかった。

修正 44 週時の NBASクラスター值と予後と の関係は，正常群と CP 群の間には自律神経系の 安定性と状態の幅のクラスターを除く他のクラス ターで, 正常群と MR 群の間には自律神経系の 安定性と誘発反応のクラスターを除く他のクラス ターで, 有意差が見られた。図 2 は 3 群の方位反 応クラスターと誘発反応クラスターの回復曲線を 示す.

\section{3. 統計学的検討}

低出生体重児 209 例を対象として統計学的検討
を行った。正常群 148 例, CP 群 17 例, MR 群 44 例であった。

新生児行動評価データの処理は, Lesterのク ラスター法に準じた。7)の補足項目は該当する他 のクラスターに振り分けた。たとえば，「敏活性 の質」の項は，方位反応クラスターに加えた. 6 つの行動学的クラスターと誘発反応クラスターに ついて検討した。

上述した 7 つの NBAS クラスターのうちどの クラスターが予後推定に関連しているかについて のロジスティック回帰分析の結果を表 1 に示し た. $\mathrm{CP}$ 群では運動，誘発反応，方位反応クラス ターが, MR 群では方位反応, 運動, 状態の幅ク ラスターが予後推定に強く関与するものと思われ た。

次に, ロジスティック回帰式から予測式を作 り,この予測式に各症例のデータを適用して, ど

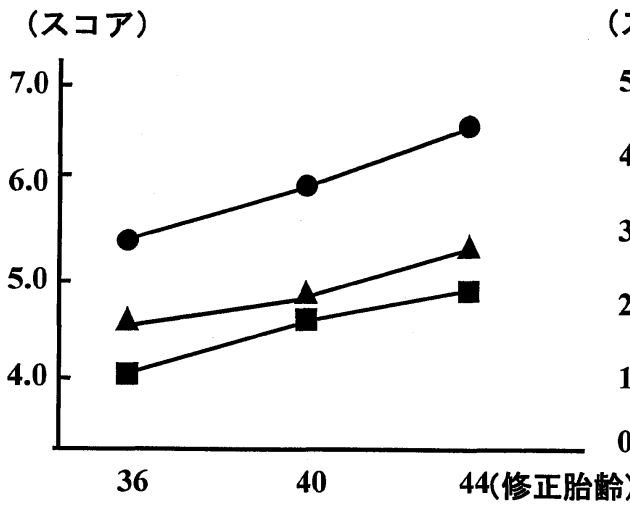

図 2 低出生体重児の方位反応(左) と誘発反応(右)クラスターの回復曲線

○は正常発達, \は脳性麻痺, 口は精神運動発達遅滞を示す.

表 1 多項ロジスティック回㷌分析による正常発達群に対する精神運動発達遅滞群と脳性麻痺群の有意な NBAS クラスターのオッズ比 (95\%信頼区間)

\begin{tabular}{llccc}
\hline & NBAS クラスター & NBAS 36 & NBAS 40 & NBAS 44 \\
\hline 精神運動発達遅滞 & 方位反応 & & $0.88(0.82 \sim 0.95)$ & $0.38(0.69 \sim 0.89)$ \\
& 運動 & $0.87(0.78 \sim 0.97)$ & $0.84(0.74 \sim 0.96)$ & $0.78(0.58 \sim 0.81)$ \\
& 状態の幅 & & & $0.89(0.80 \sim 0.99)$ \\
脳性麻痺 & 方位反応 & $0.82(0.68 \sim 0.99)$ & $0.88(0.80 \sim 0.99)$ & \\
& 運動 & $0.77(0.61 \sim 0.97)$ & $0.77(0.63 \sim 0.94)$ & $0.52(0.36 \sim 0.76)$ \\
& 自律神経系の安定 & $0.77(0.63 \sim 0.95)$ & & \\
& 誘発反応 & & $1.09(1.02 \sim 1.16)$ & $1.25(1.11 \sim 1.42)$ \\
\hline
\end{tabular}

例えば, 正常発達群と精神運動発達遅滞群の分析結果で, NBAS 36 の運動クラスターのオッズ比 $=0.87$ は, 運 動クラスター值が 1 単位増加するときに, 精神運動発達遅滞群となるリスクが $13 \%$ 減少することを示す. 
表 2 多項ロジスティック回帰モデルを適応した判別 分析の結果

\begin{tabular}{lccc}
\hline & NBAS 36 & NBAS 40 & NBAS 44 \\
\hline 正常 & 96.2 & 94.3 & 96.5 \\
精神運動発達遅滞 & 46.7 & 54.1 & 79.5 \\
脳性麻盘 & 58.3 & 57.1 & 88.2 \\
Overall percentage & 82.9 & 82.7 & 92.2 \\
\hline
\end{tabular}

正常群では 94.3 96.5\%, 精神運動発達遅滞群では 46.7 79.5\%, 脳性麻疾群では 57.1 88.2\%の割合で 判別可能で, 全体の判別精度は 82.7 92.2\%であった.

のくらいの精度で, 予後予測できるかを調べた. その結果, 正常群 94.3 96.5\%, CP 群 57.1〜 $88.2 \%$, MR 群 $46.7 \sim 79.5 \%$, と経時的に精度 は高くなり, 修正 44 週頃（3 回目）の検査では 92.2\%だった（表 2).

\section{General movements $の$ 観察}

Prechtl ら ${ }^{2)}$ およ゙ Cioni ら ${ }^{11)}$ は, 新生児期の 自発運動（general movements：GMs）の定性 的・定量的な評価所見は，脳障害の予後との関係 が強いと報告している。

全身の自発運動を 15 分以上観察して, 異常な GMs 所見が検討される. 2 つの主な異常所見と して, poor repertories, cramped synchronized

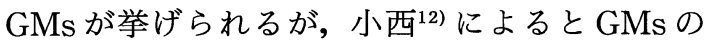
着眼点は, (1)運動の振幅, (2)速度, (3)性質, (4)連 続性，(5)空間性，(6)始まりと終わり，(7)手・指の 動きなどである。

Prechtl らは，周産期に脳障害のリスクを持つ 130 例を対象に, 出生後毎週 1 時間, 退院後は 3〜4 週ごとに 15 分間, 自発運動をビデオテープ に記録, 2 年後の発達予後との関連について分析 した。その結果，正常な fidgety GMs を示した 70 例中 67 例 $(96 \%$ ) が正常発達で, fidgety GMs が異常または欠如していた 60 例中 57 例 （95\%）が神経学的異常発達であった（49 例が脳 性麻痺で, 8 例が発達遅滞または微細な神経学的 徵候を示した). fidgety GMs 評価の特異度, 感 度は，それぞれ 96\%，95\%で，脳の超音波画像 診断の $83 \% ， 80 \%$ より高かった。

正常な fidgety movements は頸, 体幹, 四肢 の小さな振幅で, 適度に速度が変化する, 円形
の，優雅な運動の継続的流れと定義される．これ らは，注視したり，むずがったり，啼泣している とき以外の覚醒時に観察できる. 正常児の GMs は生後 6〜9 週で writhing パターンから fidgety パターンへ変化し， 14〜20 週で次第に少なくな る.

Cioni らは，未熟児における GMs 観察と 2 年 後の神経学的発達予後との関連について, 感度, 特異度, 陽性および陰性反応適中度とも, 神経学 的診察法よりも高く, とくに, 感度と陰性反応適 中度は, 修正週数 38 週から 56 週にかけて $100 \%$ だったと報告している。

我々は新生児行動評価に自発運動と姿勢反応の 評価項目を新たに加え, 評価を実施している。そ の結果, 後二者の所見と予後との関連性について は, 未熟児 78 例中 5 例が脳性麻痺となったが, 修正胎齢 36 週以降の評価で 1 例を除き脳性麻痺 を予測診断できた。

\section{画像診断}

画像所見は, 頭蓋内出血, 血流障害, 脳奇形な どの診断に欠かせないが, 能力障害とは必ずしも 一致しない, 病直型片麻痺や両麻痺, アテトーゼ 型脳性麻痺の病巣を, CT P MRI 検査で明確に することができない症例もあれば，大きな病巣が あるにもかかわらず，行動能力障害は極軽度の症 例もある. 画像所見と併せて, 新生児期からの臨 床経過が発達予後診断にとって最も価值あるもの となる。

藤村 ${ }^{13)}$ は, 早産児の脳室内出血と脳性麻痺と の関連性について, 脳室上衣下出血に比べて脳室 内出血, 片側の脳室内出血に比べて両側の脳室内 出血, さらに脳室内出血と脳室拡大の合併が, 発 達上のリスクを高める傾向があるということを明 らかにしている。また，脳実質出血では，約 $30 \%$ が正常だったが, 約 70\%は㾏性麻痺を示し, 脳実質出血例の予後は厳しいと指摘している.

さらに，未熟児・成熟児を対象に調査した，脳 室内出血を合併しない新生児期頭蓋内出血 ${ }^{14)}$ の 発達予後に関しては, $12 \%$ が脳性麻痺となってお り，実質出血の $1 / 3$ が精神遅滞を残したと述べて 
いる.

鈴木 ${ }^{15)}$ は, 未熟児の脳室周囲白質軟化症 （PVL）と脳性麻痺との関連性について, 頭部エ コーで PVL と診断した 32 症例の検討 ${ }^{16)}$ で, 1 歳半以上で発達評価を行った 28 例中 24 例 (86\%) が脳性麻痺となっており，対称性病変を 有した 17 例中全例が脳性麻瘏で, 非対称性病変 例では 11 例中 7 例が脳性麻痺で他の 4 例は正常 であったと報告している。そして非対称性病変例 での正常発達は脳の可塑性で説明できると述べて いる.

Cioni らは，リスクを伴う未熟児 66 例につい て超音波所見と 2 年後の神経学的発達予後との関 連を報告している。 66 例中 10 例は異常所見がな く，正常発達を示した。 27 例が重度脳損傷所見 (IVH III, PVL II〜IV) を有し，そのうち 4 例 が正常発達を遂げ，23 例は神経学的異常発達を 示した。一方，軽度脳損傷所見（IVH I〜II， PVL I）を有した 29 例中 19 例は正常発達を遂げ たが，10 例が神経学的異常発達（4 例は軽度， 6 例は重度）を示した。

新生児期での診断例を以下に示す。一卵性双生 児の一䄉毛膜, 二羊膜性双生児で, 双胎間輸血症 候群（双胎間に血管の吻合が存在）を伴ってい た. 生下時体重 $1,346 \mathrm{~g}$, 在胎週数 29 週 6 日, アプガールスコア 6 点/ 1 分, 6 点/ 5 分であった. 修正胎歯令 39 週の CT 検查, 40 週の超音波検査 で, 両側性脳室周囲白質軟化症（PVL）と診断 された症例であった。

新生児行動評価では, 運動, 補足項目および誘 発反応クラスターで回復が遅延した。

修正胎齢 37 週，40 週時の姿勢緊張の評価では， 腹臥位で姿勢緊張の亢進があり，頭を自由に動か すことができなかった. 斜め宙吊りテストでも， 後弓反張, 両下肢伸展などの姿勢緊張の充進があ った。

自発運動の評価では，上肢に左手関節背屈，右 手関節掌屈を伴った定型的な運動や, 振戦と攣動 性を伴った両腕，両脚の突発的な過度の運動が観 察され，下肢では左足関節内反を伴った定型的な
自発運動や，下肢全体の屈曲位または伸展位での ロック現象が観察された. 37 週，40週とも病的 所見が継続して観察されたが，44 週時には腹臥 位での姿勢緊張と上肢の自発運動に改善が見られ た.

この事例では修正胎齢 40 週の時点で痤直型両 麻痺と診断し，告知と同時に療育を開始した。脳 の可塑性を生かすためにも，超早期診断と超早期 療育が重要である。

\section{ま と め}

新生児期での脳性麻痺の診断は重度障害を除い て困難であるとはいえ，上述した行動学的および 神経学的評価, 自発運動および姿勢反応の評価に 加え, 画像診断, 脳波所見, などの総合的評価に より，高い確率で予後診断を下すことが可能であ る.

療育の段取りがあってのことであるが，新生児 期あるいはその後の発達過程で診断が明らかにな れば，率直に病態を告知し，療育指導とともに， その後の発達予測や二次障害などについても説明 すべきである.

新生児期からの療育介入は学童期, 青年期, 成 人期，高齢期を通したリハに好影響をおよぽすも のと推察される.

\section{文献}

1) Dubowitz LMS, et al : The neurological assessment of the preterm \& full-term newborn infant. 2nd Ed, CDM Vol 148, Mac Keith Press, 1999

2) Prechtl HF, et al: An early marker for neurological deficits after perinatal brain lesions. Lancet $1997 ; 349$ : 1361-1363

3) Brazelton TB, Nugent JK 編著: ブラゼルトン新生 児行動評価 (䅖山富太郎 監修, 大城昌平・他 訳). 第 3 版. 医歯薬出版, 1998

4）䅖山富太郎：新生児期の脳性麻痺の諸マーカーと超早 期療育. リ八医学 $1999 ; 36: 91-94$

5）䅖山富太郎・他：低出生体重児における脳性麻痺児の ブラゼルトン新生児行動評価の分析. リハ医学 2001 ; 38: 211-218

6) Lester BM: Data analysis and prediction. in Neonatal Behavioral Assessment Scale (ed by Brazelton TB). 2nd Ed, Lippincott, Philadelphia, 1984

7) Brazelton TB (川崎千里 訳) : The importance of early intervention with high risk infants (ハイリス 
ク児への早期介入). 小児保健研究 $1994 ； 53(3)$ : 373376

8) Blackburn ST, et al : Assessment and management of neonatal neurobehavioral development. in Comprehensive Neonatal Nursing (ed by Kennner C, et al). chapter 49, WB Saunders, Philadelphia 1991; pp 939-965

9) Als $\mathrm{H}$ : A synactive model of neonatal organization: framework for the assessment of neurobehavioral development in the premature infant and for support of infants and parents in the neonatal intensive care environment. Phys Occup Ther Pediatr $1986 ; 6: 3-53$

10）横尾京子: 新生児の神経行動学的発達とアルスのサイ ナクティブ・モデル. Neonatal Care, 1998; 11(11) : 908-913

11) Cioni G, et al : Comparison between observation of spontaneous movement and neurological examination in preterm infants. J Pediatr 1997 ; 130 : 704711

12）小西行朗: 新生児行動からみた神経異常のスクリーニ ング. 周産期医学 $1998 ; 28$ : 619-923

13）藤村正哲：早産児. 胎児・新生児の神経学（佐藤 綮・他 編).メディカ出版, 1993; pp 374-394

14）藤村正哲，竹内 徹：新生児期の頭蓋内出血の頻度. NISU'93 春季増刊 1993 ; (65) : 113-122

15）鈴木重澄：脳室周囲白質軟化症. NICU 93, 春季増刊 1993 ; (65) : 142-145

16）藤本伸治：新生児の PVL （periventrical leukomalacia）. 新生児医学体系小児医学の進歩 1992 ; '92 B : $95-104$

\section{脳性麻痺の二次障害としての機能 予後}

北海道立福祉村医療センター

佐久間和子

\section{はじめに}

脳性麻痺は早期療育が大切であるといわれてき たが, 学童期に入ると, 学校教育を受けた後に通 園センターでリハビリテーション（以下，リハ） が行われる. 高校生になると体重増加が行動能力 の低下を引き起こしてしまうので，医学的リハが 最も重要視される. 脳性麻痺の機能発達は 15〜 20 歳までであるが, 成人に達すると筋緊張のア ンバランスによる関節拘縮の進行や二次障害が出 現し始める. 医学的リハについては, 一時期行っ ても中止してしまえば，悪化するのが脳性麻痺の 特徵であるといわれている.

二次障害および症状進行の主なものは, (1)頸椎 脊髄症，(2)麻痺性股関節脱臼，(3)側彎および肺機 能低下の問題である.

脳性麻痺は障害の程度, 随伴症状, 筋緊張の状 態, 原始反射の残存, 異常姿勢などの重複障害を 示し, 発達成長の過程での複雑な問題がからみ合 い, 二次障害や症状進行が起きてくる。

脳性麻痺（身障 1 2 級）の重度身体障害者総 合援護施設で 230 名の脳性麻痺の診療にたずさわ り，6 年間経過した。このデータから私見を述べ たい.

\section{頸椎脊髄症}

平均年齢 40 歳でアテトーゼ $40 \%$, 痤直 $30 \%$, アテトーゼ十痙直 $29 \%$ ，アタキシー $1 \%$ である.

アテトーゼとしては $69 \%$, 痤直としては $59 \%$ であることになる.

最も重要なものに頸椎脊髄症がある（表 1 , 2).上肢のシビレ感, X-p での骨の変化 $\mathrm{MRI}$ 上 の異常を示す脳性麻痺者は現在 104 名いる. その 
表 1 頸椎症

\begin{tabular}{cccc}
\hline 年齢（歳代） & 入村者 $($ 人) & 頸椎症 (人) & 発生率 $(\%)$ \\
\hline 20 & 27 & 10 & 47 \\
30 & 102 & 45 & 47 \\
40 & 73 & 35 & 46 \\
50 & 22 & 12 & 54 \\
60 & 5 & 1 & 20 \\
70 & 1 & 1 & 100 \\
\hline 計 & 230 & 104 & \\
\hline
\end{tabular}

表 2 頸椎症と診断された 104 名

\begin{tabular}{lc}
\hline \multicolumn{1}{c}{ category } & (名) \\
\hline すでに診断されているもの & 14 \\
確定診断されているもの & 82 \\
X-p 上変化があるもの & 68 \\
シビレ感があるもの & 77 \\
\hline
\end{tabular}

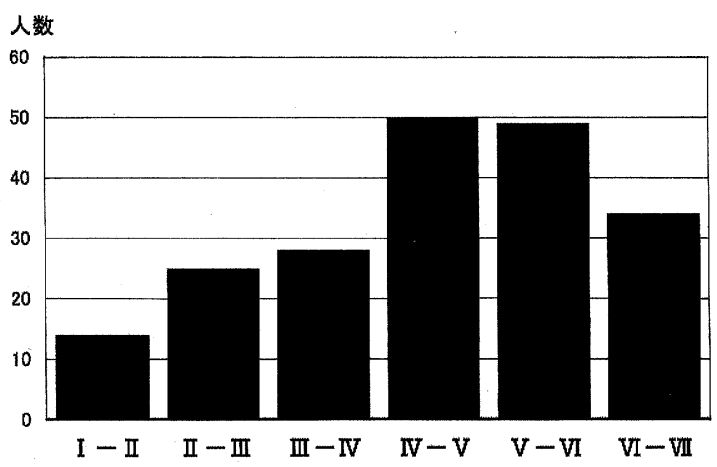

図 1 莖椎の障害部位（104 名）

後日の検查で 1 名が環軸関節に障害が発見された。

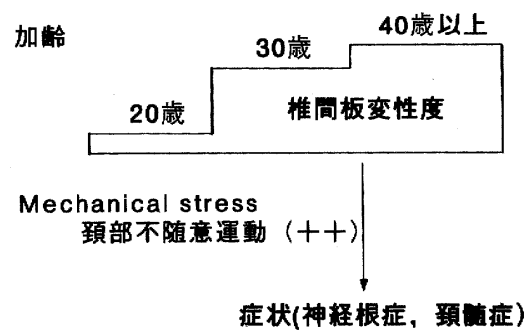

図 2 成人アテトーゼ型 $\mathrm{CP}$ の頸椎病変

中でアテトーゼは 96 名である。手術を受けた者 23 名である. 1998 年から 2002 年までに $25 \%$ 増 加した。

障害部位は各頸椎にわたっている（図 1)。環 軸関節は 1 名いる。
表 3 年齢と椎間板変性度, 最小脊柱管前後径

$\begin{array}{lcc}\hline \multirow{2}{*}{\text { 年齢 }} & \multicolumn{2}{c}{\mathrm{X} \text { 線像 }} \\$\cline { 2 - 3 } & \text {$\left.椎間板変性度 } & \text { 最小脊柱管径 }(\mathrm{mm}) \\ \hline 20 \text { 歳代 }(n=7) & 2.43 \\ 30 \text { 歳代 }(n=17) & 6.24\end{array}\right] * \begin{array}{r}* \\ 40\end{array}$

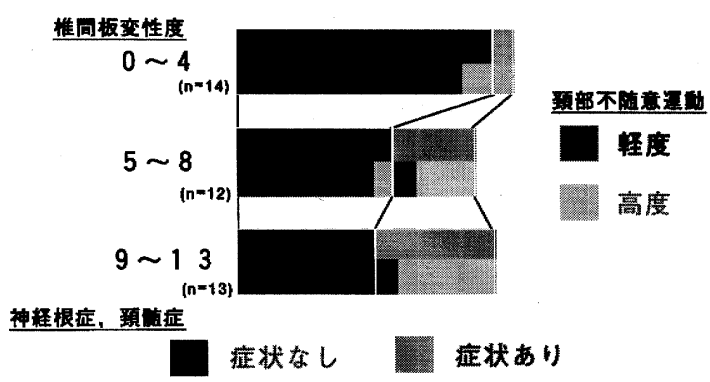

図 3 椎間板変性度と症状発生, 頸部不随意運動

また年齢が高くなるほど椎間板変性度も強くな る(図 2,3 , 表 3 ).

最小背柱管前後径も狭くなる。

頸部不随意運動が強いものほど, 椎間板変性度 も高く, 神経根症も強くなる.

幼少より頸部の抗重力筋の強化することにより 頸の振れも少なく，予防になるといわれている. 振れが大きい䚾ど頸椎脊髄症が強いように思われ る.

弛緩性麻痺になったものは 7 名経験している が, 現在 3 名が入所している.アテトーゼのパタ ーンの変化, 握力の問題, シビレ感の強弱, 肩お よび頸部の筋緊張の軽減等の問題を考えてみて, 今後諸先生のご努力をお願いしたい.

握力に関しては毎年検査を行っているが，この 6 年間で低下の認められたものがあり, 頸椎症と 関係があるかも知れない。

\section{股関節，交叉脚}

交叉脚は麻痺性股関節脱臼を起こす基因とな る. 交叉脚は, 現在 45 名認められ，1998 年〜 2002 年の 5 年間に 14 名増加した。また交叉脚は 女子の排尿時に不便で介助を要する.

股関節脱臼は小児期から起こさないよう，手 
表 4 股関節症

\begin{tabular}{lc}
\hline category & (名) \\
\hline 脱臼 & 38 \\
亜脱臼 & 28 \\
関節症 & 13 \\
骨頭変形 & 9 \\
\hline & 計 \\
\hline
\end{tabular}

術，またはリハが行われてきた。しかし療育セン ターでは 15 歳未満で 23 名が認められている.

現在では脱臼 38 名, 亜脱臼 28 名, 関節症 13 名, 骨頭変形 9 名, 合計 88 名であり, 痙直型 23 名, アテトーゼ型十痙直 64 名である（表 4).

疼痛を訴えるものが 63 名いるが，特に痛みが 強く薬を常用服用するもの 13 名で 35 歳以上の年 齢である，加齢と痛みは相関関係にあるようであ る.

入所者はつかまり立ちの可能であることを望ん でいる。それは食事が自立しなくても，トイレ動 作だけは自立したいと言っている。それには，つ かまり立ちが可能でなければならないからであ る.

\section{側彎}

要因は

1）筋緊張の立進

2) 原始反射の残存, TLRによるそり返り, ATNRによる体幹のねじれ，これらが異常姿 勢を呈する。

3）麻痺の程度の左右差

4）筋緊張の低下で抗重力作用がなく, 食事姿勢, 長期座位姿勢, 習慣性があり, 側彎, 胸部扁 平，肋骨弓隆起などの変形を呈する.

5）痤直型では，骨盤分離が悪いため長座で円背 となり後彎となる。

幼少より始まって年齢と共に増加する. 230 名中 127 名 $55 \%$ に認められる。 アテトーゼに多い.

療護の重度のものでは $91 \% に$ 認められた。

$\mathrm{S}$ 字状側彎は 12 名抒り，重度の障害ほど症状 が出やすく高度の側彎となる。

また年霜とともに増加する，成人になると座位
表 5 側彎の増強

\begin{tabular}{lc}
\hline category & (名) \\
\hline 重 度 & 21 \\
中等度 & 28 \\
軽 度 & 78 \\
\hline
\end{tabular}

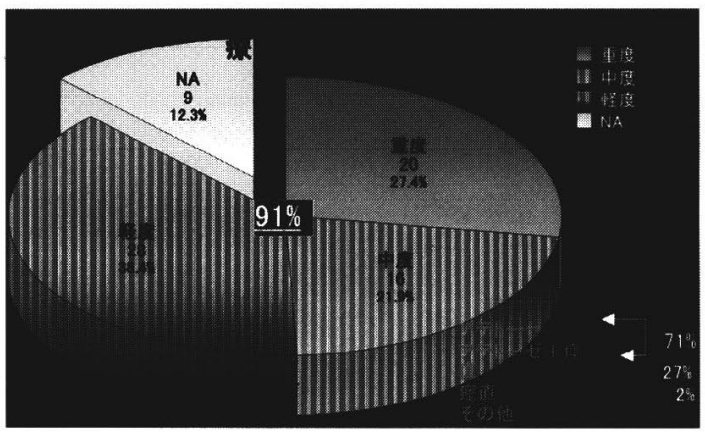

図 4 側 彎

姿勢の時間が多くなり, 習慣性側彎が増強する. 他の疾患にかかり，一般病院に入院すると体幹 は放置状態となり，側彎が進行してくる傾向があ る. 3 力月入院で $30^{\circ}$ 以上増悪した者もいる（表 5).

\section{治療}

成人では極端な改善は望めないと思う。現状維 持や加齢に伴う悪化を防ぐことが重要であろう. 手術は年齢, 変形の程度, 合併症など十分検討し た上で決定されると思う。

脊椎固定術では, 寝返りができず，車椅子の操 作が下手になる、フックがはずれてしまうことも ある。

選択的筋緊張の解離術は呼吸が楽になり，体幹 の回旋がしやすくなり, 咀嚼喂下にも良いし, ト イレ動作も向上する。しかし無理した矯正は避け るべきともいわれている.今後の諸先生のご努力 に期待したい.

立位, 歩行可能であると側彎は起きにくい.そ のため体幹の問題が重要で, 安定した座位姿勢が 大切であろう。さらに同じ姿勢をとらず，可能な 範囲で姿勢動作を変化させるように心がけるべき である。 
表 6 肺活量の低下

\begin{tabular}{cccc}
\hline category & 1998 年(名) & 2002 年(名) & 側彎 \\
\hline 1,500 以下 & 34 & 62 & 27 \\
1,000 以下 & 26 & 42 & 33 \\
500 以下 & 11 & 11 & 11 \\
\hline 計 & 71 & 115 & 71
\end{tabular}

実際は肺活量 1,500 cc 以下が全体の $50 \%$ 存在する.

職場では作業能力を上げようと側彎を増強させ る姿勢をとることが多い. 作業では対称運動, 回 旋などを行い，また変化ある姿勢をとるような仕 事を選び，体幹を動かすことに努力すべきであ る。これは頸椎症でも同じである。 作業の椅子も考慮する必要がある. 車椅子のシーティングの研究をされている.

\section{呼吸障害（肺機能低下）（表 6)}

側彎の深刻な問題は肺機能の低下にあり，呼吸 パターンの悪さに加えて呼吸量の減少にある。

胸郭の変形，側彎，アテトーゼによる呼吸パ夕 ーンが悪く，健常者に比べ肺活量が減少してく る。慢性呼吸不全による閉塞性低換気症候群にな る心配がある。

肺活量は健常者では 19 歳が最高に達し，その 後 1 年に 1 ～ $1.2 \%$ す減少するといわれている.

5 年間に 230 名中 88 名 $(38 \%)$ が減少してき た.その中で $67 \%$ が側彎者であった。

肺活量測定はアテトーゼ型では測定不確実とな りやすい. 正しい呼吸量 $\left(\mathrm{O}_{2}\right.$ 摂取量) 測定が必 要と考え, そのため呼吸機能の把握分析を行うこ ととし，札幌医大と取り組み研究を始めている。

実際は肺活量 $1,500 \mathrm{cc}$ 以下は全体の $50 \%$ 存在 する。療護 $63 \%$ が $1,500 \mathrm{cc}$ 以下である。

正常呼吸パターンの学習が大切であろう。スト レス, 不安を改善させ, 循環, 社会生活の改善, 側彎の改善, 対称性の姿勢を保つよう取り組むべ きである。

補装具の比率も図 5 の如くである.

\section{便 秘}

毎日の下剂服用者が 1998 年 32 名であったが 2002 年 46 名に増加した（14 名が増加）. 時々麻 痺性イレウスを起こすものが 5 名いる.

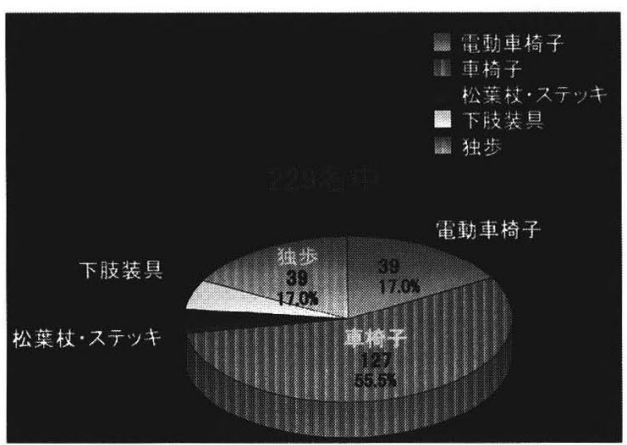

図 5 補装具の比率

表 75 年間の増加（1998～2002 年)

\begin{tabular}{|c|c|}
\hline 電動車椅子 & 9名増加（39名） \\
\hline 車椅子 & 14 名增加（127 名） \\
\hline 歩行者 & (98名) \\
\hline 交叉脚 & 14 名増加 \\
\hline 肺活量の低下 & $\begin{array}{l}1,500 \mathrm{cc} \text { 以下 } 28 \text { 名 } \\
1,000 \mathrm{cc} \text { 以下 } 16 \text { 名 }\end{array}$ \\
\hline 下剮服用者 & $\begin{array}{l}14 \text { 名増加（46 名） } \\
\text { 車椅子使用者 } 42 \text { 名 }(90 \%)\end{array}$ \\
\hline 德下因難 & 12 名となる \\
\hline 頸椎症 & 5 年で $25 \%$ (26 名) 増加 \\
\hline
\end{tabular}

\section{筋緊張}

年齢とともに増強し不眠を訴える。

飲酒がある程度すすむ. 毎日飲酒者は 27 名全 入村者の半数が男女とも週 3〜4 回飲用している.

筋緊張緩和剤，睡眠薬の常用者は 22 名いる.

胃潰瘍 7 名, 十二指腸潰瘍 3 名, 神経性膀胱炎 21 名いる (頸椎症のためと思う).

\section{嚥下困難}

Tension Athetose は年齢とともに筋の協調動 作が下手になり，筋力も低下してきて暖下困難に なってくる. 食事摄取時誤飲が多く，二次的肺炎 を起こすことが多い．胃瘻の方法もあるが現在チ ューブ栄養を行っている.

5 年間の統計としては二次障害ならびに症状進 行については表 7 のとおりである.

\section{結語}

1）思春期にどれだけケアされたかが大切.

2）訓練している者はがまんする能力ができて いる. 
表 82 症例の比較

\begin{tabular}{|c|c|c|c|}
\hline & & 45 歳, 女性 & 44 歳, 女性 \\
\hline \begin{tabular}{c|c} 
原因 \\
型
\end{tabular} & \multicolumn{2}{|c|}{$\begin{array}{l}8 \mathrm{M} \text { 早産仮死, 出生時体重 } 1,560 \mathrm{~g} \\
\mathrm{At}+\mathrm{S} \text {, IQ } 91\end{array}$} & $\begin{array}{l}8 \mathrm{M} \text { 早産仮死, 出生時体重 } 1,450 \mathrm{~g} \\
\mathrm{At}+\mathrm{S}, \mathrm{IQ} 92 \sim 102\end{array}$ \\
\hline \multirow{8}{*}{\multicolumn{2}{|c|}{$\begin{array}{l}\text { 頸のすわり } \\
\text { えんこ } \\
\text { 這い這い } \\
\text { つまかり立ち } \\
\text { 這い這い四つ這い } \\
\text { 床からの立ち上がり } \\
\text { 独歩 } \\
\text { 言語 }\end{array}$}} & 2 歳 & 1 歳 \\
\hline & & 2 歳 & 3 歳 \\
\hline & & 2 歳 & 3 歳 \\
\hline & & 2 歳 & \\
\hline & & $2 \sim 3$ 歳 & $3 \sim 4$ 歳 \\
\hline & & & \\
\hline & & 8 歩位（実用性なし） & 7〜8 歩（実用性なし） \\
\hline & & アテトーゼ言語 & アテトーゼ言語 \\
\hline 訓練 & \multicolumn{2}{|c|}{$\begin{array}{l}\text { 母子入院一度したきり全く訓練しない } \\
\text { 交叉脚+歩行器で移動 股関節に著しいいたみ } \\
\text { 下肢駆動車椅子使用（後ろ向きで） } \\
\text { 養護学校, 小中高卒 } \\
\text { 職業訓諫所一村に }\end{array}$} & $\begin{array}{l}\text { 生後通園センターに通い, その後 } 6 \text { 歳まで療育センターに } \\
\text { 入院, 中学卒業まで } 10 \text { 年間入院して訓練していた. } \\
\text { 立位 }(-) \text { 右ステッキで } 2 \text { 分立つ } \\
\text { 左ステッキで } 30 \text { 秒左右 }(+) \\
\text { 尖足内旋交叉脚 }(+) \text { ア腱延長術 } \\
\text { LLB で歩行訓練 } \\
\text { 療育センター重度更生指導所, 松葉歩行, 訓練センター- } \\
\text { 村 }\end{array}$ \\
\hline $\begin{array}{l}\text { 現在 } \\
\text { 職業 }\end{array}$ & \multicolumn{2}{|c|}{$\begin{array}{l}\text { 入村後電動椅子の生活（入村 } 2 \text { 年目より） } \\
\text { 印刷，コンピューター }\end{array}$} & $\begin{array}{l}\text { 電動車椅子の生活（1990 年より） } \\
\text { 刷刷, コンピューター }\end{array}$ \\
\hline 二次障害 & \multicolumn{2}{|c|}{$\begin{array}{l}\text { (1)頸椎脊椎症：上位〜下位まで } \\
\text { シビレ感 }(+), \text { 握力 } \\
\text { (2)側彎 : 中等度 }(+) \\
\text { (3) LCP : 両側の強い疼痛 }\end{array}$} & $\begin{array}{l}\text { (1)頸椎症 }(+) \text { : 椎骨の間は少し狭い } \\
\text { (2)側彎：軽度 } \\
\text { (3) LCP }(-) \text { : 疼痛 }(-) \text {, 交叉脚 }(-) \\
\text { (4)卜イレ自立：箸を使用 }\end{array}$ \\
\hline 生活 & \multicolumn{2}{|c|}{$\begin{array}{l}\text { (4)筋緊張強く トイレ半介助フォーク使用 } \\
\text { 仕事もできにくくなってきた }\end{array}$} & スポーツ大会に出席 \\
\hline
\end{tabular}

3）アテトーゼの未梢部にあると軽度傾向にあ る.中枢部にあると重度傾向にある。

4）成人思春期を過ぎると筋緊張が急に強くな る.

5）Hip の疼痛が出てくる.

以上から不眠になりやすい. 筋弛緩剤, 酒に頼 るようになる。

6）仕事は生きがいになる，仕事は，重症度 (体力を含めた), 障害部位, 型, 二次障害, 好み などを総合的に考慮して選ぶべきであり, 頸椎症 は頭の屈曲のみの強い仕事は選ばず, ある程度 頸・体幹の変換を考慮して選ぶ. 結婚すること も, 協力, 病変に対するお互いのかばい合い, 理 解と安心があって結構と思う.

症例として 2 名の CP の差を発表する（表 8).ご一考いただきたい. 


\section{早期療育から継続的リハビリテーシ ヨン施行 25 年後の成人脳性麻痺臨 床像}

大阪府立身体障害者福祉センター

鈴木 恒彦

ボバース記念病院

柴田 徹, 藤田良

南大阪療育園

梶浦 一郎, 大下 舜治

はじめに

我が国で脳性麻痺（以下 CP）の早期発見・早

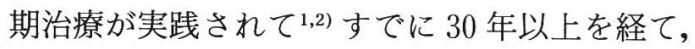
CP の早期発見・治療の考方方は一般的になっ た.しかし CP の早期発見・早期療育が CP の病 態像にどのような影響を及ぼしたかについては, 比較対照群の設定が難しいために客観的検証に至 つていない。このため, 早期療育を経験した乳幼 児の長期的な療育経過を追跡することによって, 変化する病態像のパターン化される傾向と治療開 始年齢 (月齿) との関係や, 今後に残された解决 すべき問題点等をまず明らかにする必要があ る3). 早期療育 10 年の経過観察の結果に扔いて
は，これまでのところ移動能力や就学形態で見る 限り良好な傾向を示している4,5). しかしその後 に成人に達した CP の日常生活が，どのように自 立しうるかの問題についての報告はきわめて少な w.

今回 CP として 4 歳未満から早期に療育の介入 が行われ，その後に同一治療環境の下で，同一の 治療概念で, 限定されたセラピストと医師によ り，25年以上にわたり追跡された症例を調査し えたので，その結果から脳性麻痺の機能予後につ いて考えてみたい。

\section{方法と対象}

1970 年 5 月 1973 年 12 月に, 4 歳末満で南大 阪療育園を初診し，CPの確定診断の下に，その 後に療育園からボバース記念病院へ継続してリハ ビリテーション（以下，リハ）治療を含む医学的 管理が行われた 804 例の長期療育 CP 览を対象 に, 後方視的方法により追跡調查を行った。

このうち, 20 歳以前に自立生活が獲得（一部 患者・家族自らの判断で通院中止を含む) された 例, 経過途中での死亡例, 行方不明例を含む 534 例 $(66 \%)$ は，規定の医療的管理から外れたた め, 検討対象群から除外した。また, 1993 2000 年で医療的管理が必要であった残り 270 例のう ち, 治療開始時の発達段階が独歩不可（または未

1970 1973年初診の4城末満CP児804例の

25年以上の後方視的追跡結果

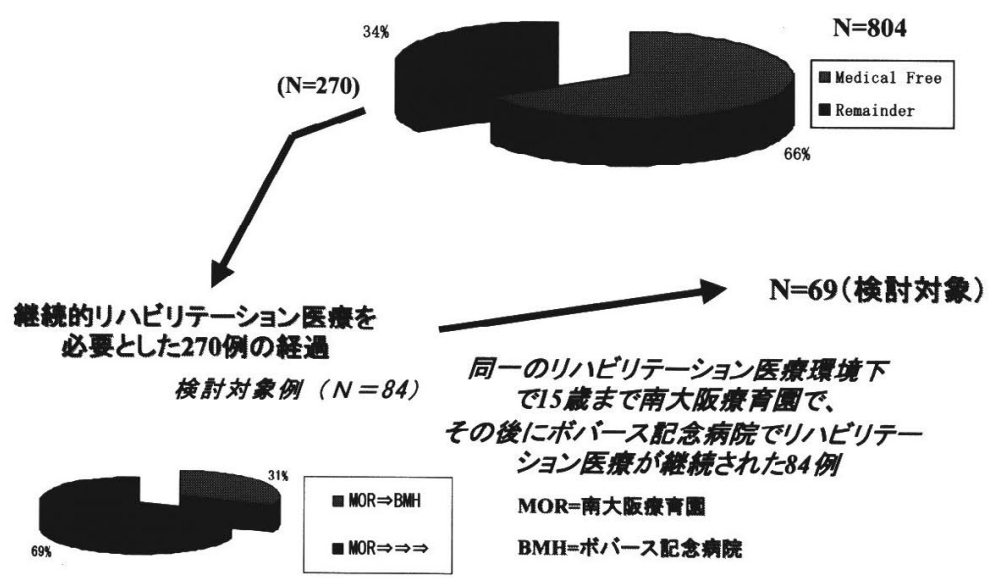

図 1 検討対象例の抽出方法 $(N=69)$ 
歩行）以下の状況の症例だけを選び，継続的な介 入療育の環境を同一にする目的で，同じ医師とセ ラピストにより 15 歳までの療育が継続して南大 阪療育園で行われ，15歳以降にボバース記念病 院でのリ八治療に移行し，21～31 年（平均 26.5 年）間追跡できた 84 例を今回の検討対象とした。

図 1 は 804 例から今回検討対象とした 69 例を 抽出した過程を示す。当初対象とした 804 例の中 で継続的な医療的管理から外れた症例を除いた （対象患者 804 例から 270 例に絞り込み）後に， 一定の療育環境の下 ${ }^{6)}$ に, 現在もボバース記念病 院に通院している症例のみが抽出された（同 270 例から 84 例に絞り込み)。また治療的介入の均一 性を保つため，追跡期間内に大阪地域圏外での異 なった方法によるリハ治療経験者や，リハ治療内 容が不明瞭な症例 15 例をさらに除外し, 最終的 には現在も年に 2 4 回の医学的管理が続いてい る 69 例について以下の 4 項目を調査した。(1)初 診時年歯 (月歯)，(2)麻瘏のタイプ，(3)現在の移 動能力, (4)就業状況についてである. 69 例の内 訳 は, 男/女 $=42 / 27$, 現在の年齢は $23 \sim 34$ 歳 (平均 27.7 歳) であり, 入院治療と通院治療の比
率は個々の例で異なっているものの，全例学童期 まで理学療法/作業療法/言語療法がボバースアプ ローチの概念の下にマンツーマンで系統的セラピ 一が行われ，必要に応じて整形外科手術も加えら れた. (4)の就業状況の分類は, Bottos らによる 1934〜1980 年の間に生まれた成人 CP の病態像 と小児期の療育との関係7)で用いられた就業パ夕 ーンの分類に従った。

\section{結果}

表 1 は最初に対象とした 804 例の CP の初診時 年歯令と初診時の診断麻痺型を示す. 0 歳代 175 例， 1 歳代 232 例 と，対象例の $50.6 \%$ が $0 \sim 1$ 歳 代であった。

表 2 は最終的な検討対象となった 69 例の初診 時年齢と現在の麻痺型を示す。 0 歳代 22 例， 1 歳 代 26 例， 2 歳代 11 例， 3 歳代 10 例であり，初診 時年齢の構成比率は図 2(a)である.48例 （70\%）が 0１歳であったことが特徵的である. 図 2(b) は成人に達した後の対象症例の全体の麻 痺型の構成比率を示し, (1)㾏直型両麻痺 25 例, (2)㾏直型四肢麻痺 13 例，(3)アテトーゼ型四肢麻

表 $11970 \sim 1973$ 年に 4 歳未満で南大阪療育園を初診時の麻痺型(人)

\begin{tabular}{ccccccccc}
\hline \multirow{2}{*}{ 初診時年䤮 } & \multicolumn{7}{c}{ 麻痺型（初診時） } & \multirow{2}{*}{ 計 } \\
\cline { 2 - 7 } & Unclassified & S. Q. & S. D. & S. H. & Athe. & Atax. & Mix. & \\
\hline 0 歳 & 47 & 38 & 26 & 18 & 43 & 2 & 1 & 175 \\
1 歳 & 46 & 38 & 50 & 44 & 48 & 1 & 5 & 232 \\
2 歳 & 40 & 23 & 62 & 32 & 36 & 3 & 2 & 198 \\
3 歳 & 43 & 26 & 60 & 24 & 38 & 3 & 5 & 199 \\
\hline 計 & 176 & 125 & 198 & 118 & 165 & 9 & 13 & 804 \\
\hline
\end{tabular}

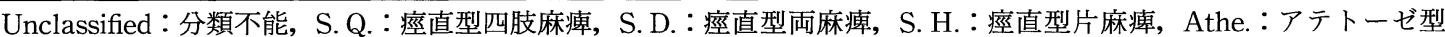
麻瘴, Atax.：失調型麻痺, Mix.：混合型麻痺

表 2 検討対象群の初診時年齢と現在（成人 $\mathrm{CP}$ ) の麻痺型(人)

\begin{tabular}{|c|c|c|c|c|c|c|c|}
\hline \multirow{2}{*}{ 初診時年齢 } & \multicolumn{6}{|c|}{ 麻痺型（成人） } & \multirow{2}{*}{ 計 } \\
\hline & S. Q. & S. D. & S. H. & Athe. & Atax. & Mix. & \\
\hline 0 歳 & 8 & 5 & 2 & 3 & 0 & 4 & 22 \\
\hline 1歳 & 2 & 10 & 4 & 4 & 2 & 4 & 26 \\
\hline 2 歳 & 2 & 6 & 1 & 1 & 1 & 0 & 11 \\
\hline 3 歳 & 1 & 4 & 0 & 4 & 0 & 1 & 10 \\
\hline 計 & 13 & 25 & 7 & 12 & 3 & 9 & 69 \\
\hline
\end{tabular}

S. Q.：痙直型四肢麻疩，S. D.：瘃直型両麻痺，S. H. :痓直型片麻痺，Athe.：アテトーゼ型麻痺，Atax.： 失調型麻瘏, Mix.：混合型麻痺 
(a)

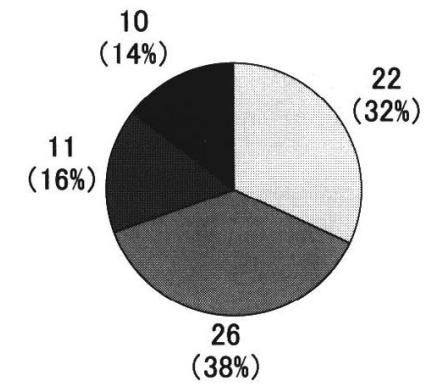

(b)

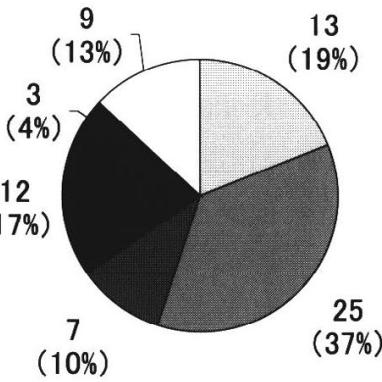

図 2 (a) 初診時年齢分布 $(N=69)$ と (b) 現在（成 人 CP）の麻痺型分布 $(N=69)$

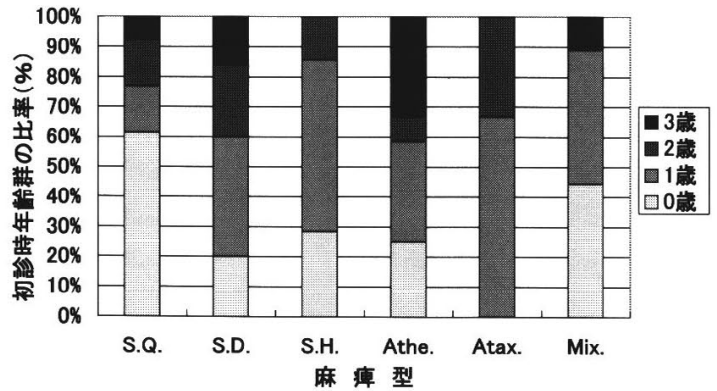

図 3 麻痺型に占める初診時年齢群

痺 12 例, (4)混合型麻痺 9 例, (5)痙直型片麻痺 7 例，6失調型麻痺 3 例であった。これら各麻痺型 の中に占める初診時年齢の構成比率が図 3 であ る。

図 4(a) は初診時年齢ごとの獲得された移動能 力の分布を示す. 獲得された移動能力の全体をみ ると, 独歩 27 例 $(39.1 \%)$ ，車椅子 22 例 $(31.9 \%)$, 杖歩行 10 例, 電動車椅子 7 例, 電動 車椅子十杖歩行，車椅子十杖歩行，車椅子+独歩 が各 1 例ずつであった。図 4 ( b ) は各麻痺型の移 動能力を示す. 痙直型両麻痺では独歩 10 例と杖 歩行 9 例, 車椅子 4 例, 電動車椅子+杖歩行, 車

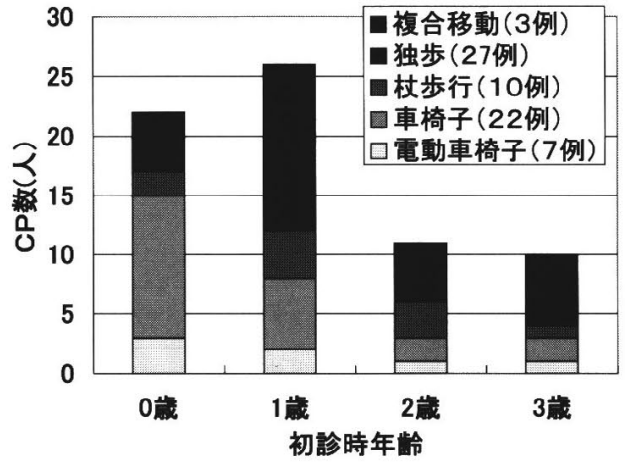

(a)

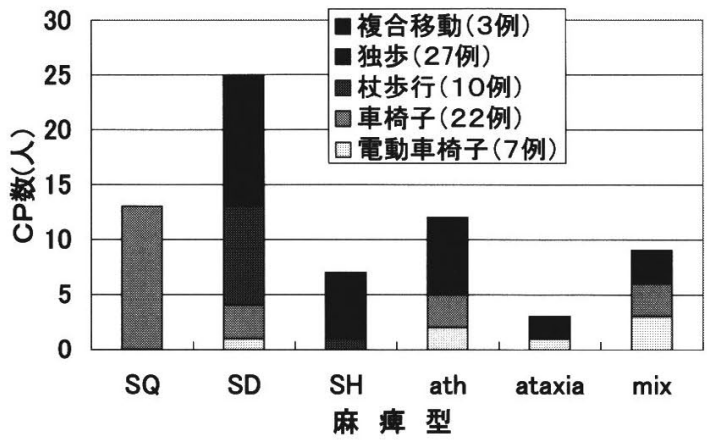

(b)

図 4 獲得移動能力の比較

(a) 初診時年齢と獲得移動能力, ( b ) 各麻痺型にお抢る獲 得移動能力

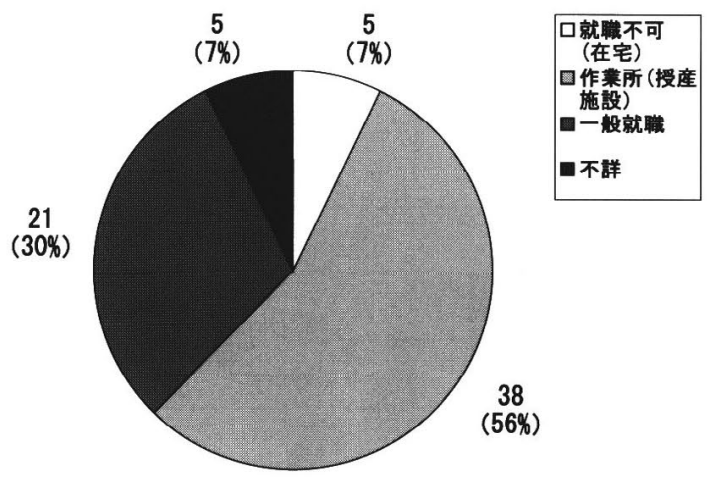

図 5 就業パターン $(N=69)$

椅子十杖歩行各々 1 例であった。痙直型四肢麻痺 では全例車椅子，アテトーゼ型麻痺では独歩 6 例, 車椅子 3 例, 電動車椅子 2 例, 車椅子十独歩 1 例であった。混合型麻痺では独歩 3 例，車椅子 3 例, 電動車椅子 3 例, 痙直型片麻痺では独歩 6 
例, 杖歩行 1 例, 失調型麻痺では独歩 2 例, 電動 車椅子 1 例であった。

Bottos $ら^{7)}$ の就業パターンの分類に従えば, 図 5 の現在の就業パターンでは, 少なくとも 86\%の症例が何らかの就業を得ていた。3 例 （55.1\%）が作業所（または授産施設）への通所， 21 例 $(30.4 \%)$ が一般就職，5 例が在宅，5 例は 不祥であった。図6(a) は獲得された移動能力毎 の就業パターンを示し, 21 例の一般就職者の内 訳は, 独歩が 12 例, 杖歩行が 6 例, 電動車椅子 2 例, 車椅子十独歩 1 例であった。一方全く就業 に至らない群は, 全例車椅子群に含まれていた。

図 6(b) は各麻痺型と就業パターンとの関係を示
し， 21 例の一般就職者は，痙直型両麻痺 25 例中 16 例, 混合型麻痺 9 例中 3 例, アテトーゼ型麻 痺 12 例中 1 例, 㽷直型片麻痺 7 例中 1 例であり, 痙直型四肢麻痺群と失調型麻痺群の中では皆無で あった. 図 6(c) は初診時年齢毎の就業パターン 分布を示し, 各年齢群の中で 0 歳群 22 例はすべ ての就業パターンにわたって分布していた。

\section{考察}

本研究の対象群の初診時（1970 年）の頃，す でに Köng (1966) ${ }^{8)}$ や Bobath ら (1967) ${ }^{9)}$ によ る先進的 CP 早期治療の報告がなされていたが, 当時の我が国の CP 療育環境の常識から考えれ

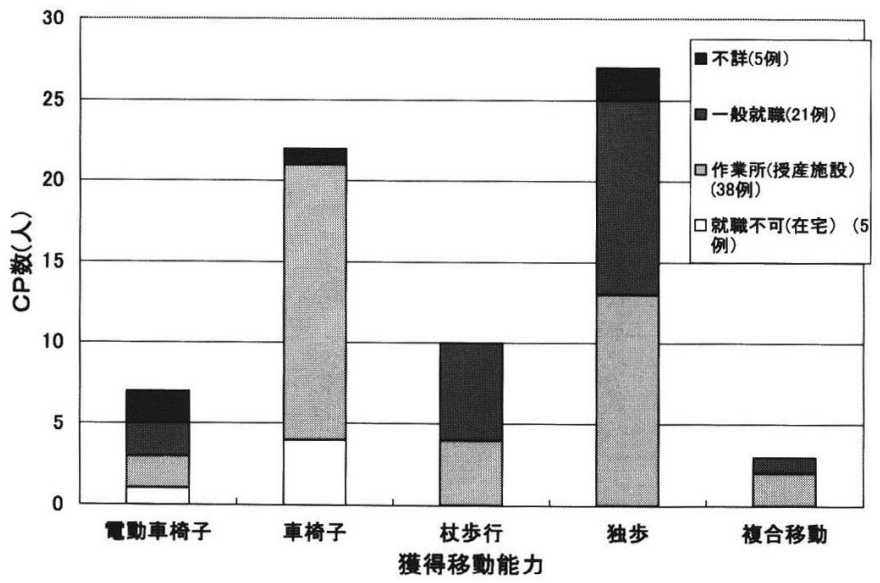

(a)

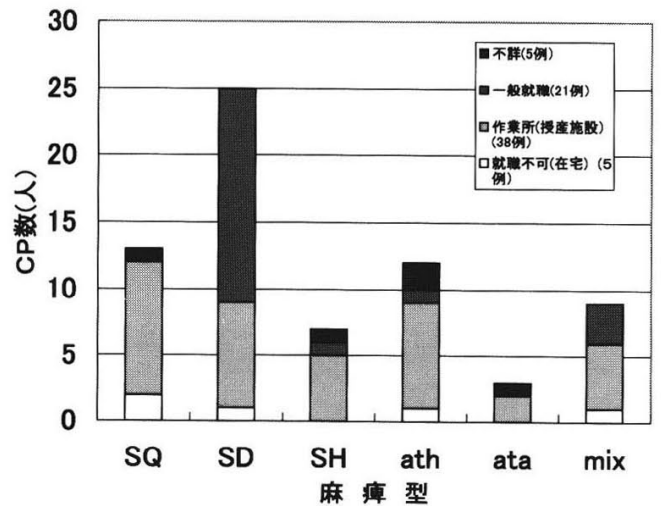

( b )

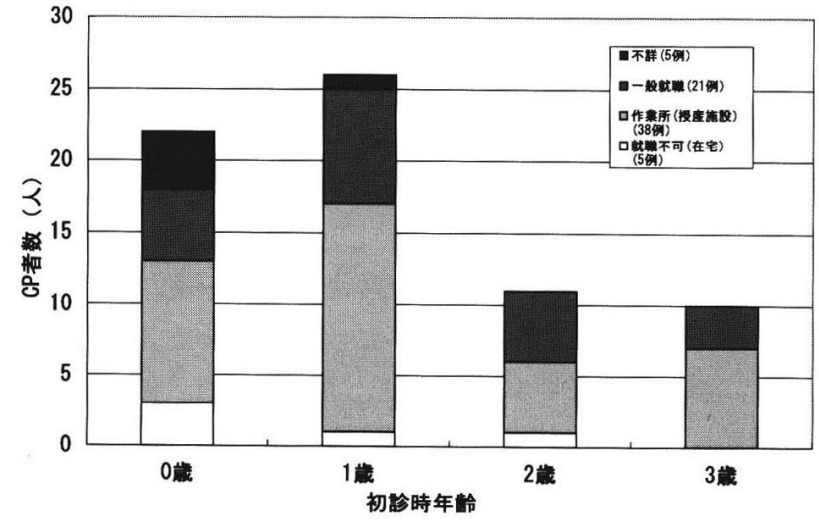

(c)

図 6 獲得移動能力，麻疾型，初診時年齢における就業パターンの比較 （a ) 各獲得移動能力に占める就業パターン, (b ) 各麻㾇型における就業パターン, (c) 初診時年歯令と就業パターン 
ば，表 1 の対象例の 407 例（50.6\%）と表 2 の 48 例 $(70 \%)$ は 0 1 歳代であり，療育開始年齢 が極めて早く, 我が国最初の早期療育の試みとし て位置づけられる. 検討母集団の特性は, 乳幼児 期から成人に至る約 25 年間にわたり，継続的な 医療管理の必要な 270 例だけが抽出されており (図 1), 医療的には重症な CP が今回の検討対象 群であったことをうかがわせる。その中でさら に, 初診時の歩行不可の発達段階の統一と, 均一 な療育環境の設定のため選ばれた 69 例中の $70 \%$ が 0〜1歳代であったことは, 運動発達が 10 カ月 以下の若年の乳幼児 $\mathrm{CP}$ を心とした症例の検討 であることを意味する.このことは図 2,3 で示 される初診時年歯の分布と現在の麻痺型の分布, 両者の関係図等でも明らかであり, 四肢麻痺に占 める初診 0 歳児の割合の大きさからすれば, 初診 時若年の症例ほど重症であった傾向が推測され る.これは, 図 4(a) の獲得された移動能力でも 同様傾向であり，他年齢に比べ 0 歳初診群では独 歩と杖歩行の獲得比率が少ない. あるいは今回の 検討母集団の抽出経過からすれば，必然的にもた らされた療育結果かもしれない.このことは, 早 期に初診した乳児は，1歳以降の幼児に比べて脳 障害の重度な例が多くを占めていたことをうかが わせる結果ともいえる。「早期に CP と診断がで きる場合は重症が多く, 軽症の場合は年長になる まで診断が難しい」という当時の早期診断の技術 水準を示すものかもしれない. 図 4(b) の麻痺型 と移動能力との関係は, 麻痺に伴う上下肢機能障 害レベルに依存した必然的移動能力がわかる。

図 5 の就業状況では $30 \%$ の一般就業がみられ, Bottos らのイタリアでの $17.7 \%$ に比べると良好 な結果であったが, 成人 CP の就労については, 単純に比較できない要素が多く, 様々の問題点を 考慮する必要があるように思える。一般的には, $\mathrm{CP}$ 固有の問題よりもその時代の社会環境要因が 優位であり, 特に, その経済と労働環境, 福祉施 策に左右される部分が多い.しかし $66.1 \%$ が就 労できないBottos らの早期療育と無関係な成人 $\mathrm{CP}$ の報告に比べ, 我々の早期療育後の成人 $\mathrm{CP}$ では不詳群を含めても $14 \%$ が不就労であったこ
とは，EU 諸国とわが国の社会環境の差異だけは 説明できないように思えた。一方図 6(a) の移動 能力毎の就業パターンの一般就業の分布をみる と, 電動車椅子 2 例を除けば, 歩行能力（独歩, 杖歩行）を有する症例の方が車椅子症例に比べて 就業比率が高く, CP の就労では, 単なる移動能 力より歩行能力の自立が求められているようにも みえた. あるいは，一般就業のために必要な就労 能力は, 歩行能力の自立と密接な相関を持つのか もしれない. Bottosらによれば，CPの就労に は, 神経学的麻痺の型よりも知的発達レベルの方 が強く相関したと述べられているが，図 6(b)の 麻痺型との関係から，麻痺に伴う ADLの自立に も密接な上肢機能の障害もまた一般就業を難しく しているようにみえた。すなわち，これらに深く 関わる適切な認知機能の発達と, それに繫がる社 会性や知的面での発達が成人 CP では十分ではな い状況が推測された。

これらの結果は, 社会的適応能力の発達が末成 熟（または不十分）なままでは, 成人 CP の一般 就業は難しく, 何らかの社会的援護の必要性を意 味するのかもしれない. 早期療育によってこれら が解決できる問題ではないことは, 図 6(c) から 明らかであるが, CP 療育の開始にあたって, 早 期よりこのような問題意識を持って療育目標を考 えることは重要であろう。さらに周産期医療や新 生児医療の進歩に伴って, 以前とは異なった病態 の CP が増えている昨今, 早期療育に継続した体 系化された幼児療育や学童療育の総合療育のあり 方が改めて問い直されているように思える。また その後の多くの成人 $\mathrm{CP}$ で避け得ない, 二次障害 に対する治療体系の確立も急がれる課題であろ $う^{10,11)}$.

\section{結語}

$\mathrm{CP}$ 診断後から 15 歳までの南大阪療育園と, その後ボバース記念病院での継続した療育を必要 とした歩行不可の 4 歳未満の乳幼児 69 例につい て, $21 \sim 31$ 年 (平均 26.5 年) 間の後方視的検討 を行った. 検討症例は長期にわたり医療管理の必 要な症例であり, 初診時の乳児群ほど重症であっ 
た. 成人後の麻痺型の構成は, (1)㾏直型両麻痺 25 例, (2)痙直型四肢麻痺 13 例, (3)アテトーゼ型 四肢麻痺 12 例, (4)混合型麻痺 9 例, (5)㾏直型片 麻痺 7 例, (6)失調型麻痺 3 例であった。獲得移動 能力は, 独歩 27 例 $(39.1 \%)$, 車椅子 22 例 (31.9\%), 杖歩行 10 例, 電動車椅子 7 例, 電動 車椅子十杖歩行, 車椅子十杖歩行, 車椅子十独歩 が各 1 例ずつであった. 就業状況は, 38 例 (55.1\%) が作業所（または授産施設）への通所, 21 例 (30.4\%) が一般就職，5例が在宅，5 例は 不祥であった. 比較対照群に基づく CP 早期療育 の効果について, 客観的判定は出来なかったが, 成人 CP の就労等には歩行能力（杖歩行を含む）

の自立が重要であり, 社会性や知的面での発達を 促すための乳児期からの体系的療育が不可欠であ ることが示唆された。

\section{文献}

1）紀伊克昌：脳性まひ児の超早期訓練の実際. 理学療法 と作業療法 $1972 ； \mathbf{6}: 585-602$

2）梶浦一郎：脳性まひ児の超早期治療とボバース法. 手 足の不自由な子どもたち. 日本肢体不自由児協会 $1973 ; \mathbf{1 7 0}: 2-3$

3）五味重治：脳性まひ児のリハビリテーション. 医学書 院, 東京, 1980

4）梶浦一郎: 脳性麻痺早期治療は有効かーボバース法の 立場から一. 脳性麻痺(5) (三宅良昌 編)。協同医書出 版社, 東京, $1985 ; \mathrm{pp}$ 30-33

5）鈴木恒彦, 佐藤一望, 諸根 涁, 手塚主夫, 高橋孝文: ボバースアプローチに沿った 7 年間の治療成績一外来 通園治療における自力歩行と就学状況からの検討一. 脳性麻瘏(5) (三宅良昌 編)。協同医書出版社, 東京, 1985 ; pp 34-48

6）Finnie NR 編著（梶浦一郎，鈴木恒彦 訳）：脳性まひ 児の家庭療育. 医歯薬出版, 東京, 1999

7) Bottos M, Feliciangeli A, Sciuto L, Gericke C, Vianello A : Functional status of adults with cerebral palsy and implications for treatment of children. Dev Med Child Neurol 2001; 43 : 516-528

8) Köng E : Very early treatment of cerebral palsy. Dev Med Child Neurol 1966; 8 : 198-202

9) Bobath $B$ : The very early treatment of cerebral palsy. Dev Med Child Neurol 1967 ; 9 : 373-390

10）梶浦一郎: 特集 脳性麻痺の二次障害/総論; 脳性麻 痺の二次障害. 総合リハ $1988 ; 26: 309-313$

11）佐藤一望: 総説 脳性麻盘の二次障害. リ八医学 $2001 ; 38$ : 775-783

\section{脳性麻瘦の臨床像の変化と予後予測}

東京都立北療育医療センター

\section{中島雅之輔}

\section{はじめに}

この数十年間は新生児医療の進歩が目覚まし く,それに伴い脳性麻痺の臨床像も変化してき た. 我々は長年脳性麻痺の予後予測について調 査・発表してきたが1,2), 対象となる症例の世代 間での医療の質にも格段の変化が存在するので, これまで一括して分析してきた世代を 3 群に分 け，3群間の差異を項目ごとの調査結果に基づい て分析，検討したので報告する．また，脳性麻痺 の予後予測については，ロジスチック回帰分析 （logistic regression analysis）により検討したの で併せて報告する.

\section{各世代間の差異についての検討}

\section{1. 対 象}

当センターに 3 歳以下で初診し, 20 歳以上ま で追跡可能であった脳性麻痺 308 例を対象とし た. 年齢は $20 \sim 41$ 歳, 平均 27.2 歳. 男性 196 例，女性 112 例であった。麻痺型は病直型 256 例，アテトーゼ型 119 例（重複を含む）であっ た。麻痺領域は四肢麻痺 177 例, 両麻痺 87 例, 片麻痺 25 例，その他 19 例であった。これらのう ち大島分類で重症心身障害に含まれるものは 79 例であった。

\section{2. 方 法}

表 1 に示すとおり，周生期，新生児期，幼児期 の既往歴, 診断, 発達歴, $\mathrm{ADL}$, 側弯・股脱, 知的障害の程度など 50 項目を調査した. その後, (1)臨床像の変化を 3 世代，すなわち $\mathrm{A}$ 群 $20 \sim 24$ 歳 (115 例), B 群 25〜29 歳 (99 例), $\mathrm{C}$ 群 30 歳 以上 (94 例) に分け, 群間で調查項目に関し著 明な差が存在するかどうかを $\chi^{2}$ 検定で検討し 
表 1 調 査 表

\begin{tabular}{|c|c|c|c|c|c|c|c|c|c|}
\hline No & \multicolumn{3}{|c|}{ カルテNo } & 氏名 & \multicolumn{3}{|c|}{ 生年月日 } & \multicolumn{2}{|l|}{ 年齡 } \\
\hline \multicolumn{2}{|l|}{ 1.性 } & \multicolumn{2}{|l|}{ 10.痤筆発作 } & \multicolumn{2}{|l|}{19.10 (成人) } & \multicolumn{2}{|c|}{ 28.健廉状態 周 新 } & \multicolumn{2}{|l|}{ 35.重泟心身障害 } \\
\hline 男 & 1 & 発作 $(-)$ & 1 & $80 \leqq$ & 1 & 良 & 1 & 重心(-) & 1 \\
\hline 女 & 2 & 発作 $(+)$ & 2 & $50 \leqq<80$ & 2 & 不良 & 2 & 重心(+) & 2 \\
\hline \multicolumn{2}{|l|}{ 2.初詥月齡 } & 発作 $(++)$ & 3 & $25 \leqq<50$ & 3 & きわめて不良 & 3 & \multicolumn{2}{|l|}{ 36.通團経験 } \\
\hline $0 \sim 4 M$ & 1 & \multicolumn{2}{|l|}{ 11.摄食状況 } & $<25$ & 4 & \multicolumn{2}{|c|}{ 29.健康状態 幼児 } & 経験 (+) & 1 \\
\hline $5 \sim 8 M$ & 2 & 良 & 1 & \multicolumn{2}{|l|}{ 20.てんかん } & 良 & 1 & 経験 (-) & 2 \\
\hline $9 \sim 11 \mathrm{M}$ & 3 & 不良 & 2 & てんかん(ー) & 1 & 不良 & 2 & \multicolumn{2}{|l|}{ 37.入圈経験 } \\
\hline $1 \sim 2 Y$ & 4 & きわめて不良 & 3 & てんかん(+) & 2 & きわめて不良 & 3 & 経験(+) & 1 \\
\hline $3 Y \sim$ & 5 & \multicolumn{2}{|l|}{ 12.脳奇形 } & \multicolumn{2}{|l|}{ 21.PT回数 } & \multicolumn{2}{|c|}{ 30.最高移胆能力 } & 経験(） & 2 \\
\hline \multicolumn{2}{|l|}{ 3.未勲性（1)体重 (g) } & 脳奇形 $(-)$ & 1 & きわめて良 & 1 & 独歩 & 1 & \multicolumn{2}{|l|}{ 38.股関節脱白 } \\
\hline $4000 \leqq$ & 1 & 脳奇形 $(+)$ & 2 & 良 & 2 & 松葉杖歩行 & 2 & 脱臼 $(-)$ & 1 \\
\hline $2500 \leqq<4000$ & 2 & \multicolumn{2}{|l|}{ 13.脳損傷 } & 不良 & 3 & 四つ這い & 3 & 片側脱臼 & 2 \\
\hline $1500 \leqq<2500$ & 3 & 脳損傷 $(-)$ & 1 & \multicolumn{2}{|l|}{ 22.摄食(ADL) } & 时逪い & 4 & 両側脱臼 & 3 \\
\hline$<1500$ & 4 & 脳損傷 $(+)$ & 2 & 自立 & 1 & 曹返り & 5 & \multicolumn{2}{|l|}{ 39.暃柱側弯 } \\
\hline \multicolumn{2}{|l|}{ 4.未熟性 (2) } & \multicolumn{2}{|l|}{ 出血, 感染 } & 半自立 & 2 & 移動不可 & 6 & 側弯 $(-)$ & 1 \\
\hline LFD & 1 & \multicolumn{2}{|l|}{ 14.彭断 (1) } & 全介助 & 3 & \multicolumn{2}{|c|}{ 31.上钎到達年齡 } & C-curve & 2 \\
\hline AFD & 2 & 痤性 $(-)$ & 1 & 23.排泄 (ADL) & & $0 \sim 5 Y$ & 1 & S-curve & 3 \\
\hline SFD & 3 & 痤性 $(+)$ & 2 & 自立 & 1 & $6 \sim 11 Y$ & 2 & 40.側窝発生年齡 & \\
\hline 5.脳損傷 & & 15.鲳断 (2) & & 半自立 & 2 & $12 \sim 17 Y$ & 3 & $0 \sim 5 Y$ & 1 \\
\hline 仮死 (一) & 1 & アテトーゼ(ー) & 1 & 全介助 & 3 & $18 Y \sim$ & 4 & $6 \sim 11 Y$ & 2 \\
\hline 仮死 $(+)$ & 2 & アテトーゼ(+) & 2 & 24.更衣(ADL) & & 32.移趿能力 & & $12 \sim 17 Y$ & 3 \\
\hline 6.黄㾝 (1) & & 16.崄断 (3) & & 自立 & 1 & 独步 & 1 & $18 Y \sim$ & 4 \\
\hline 正常 & 1 & 失調 $(-)$ & 1 & 半自立 & 2 & 松葉杖歩行 & 2 & 側弯 $(-)$ & 5 \\
\hline 光線療法 & 2 & 失調 $(+)$ & 2 & 全介助 & 3 & 四つ這い & 3 & & \\
\hline 交換輸血 & 3 & 17. 麻㾝領域 & & 25. 霅語 & & 时這い & 4 & & \\
\hline 強 処置 $(-)$ & 4 & 対麻㾝 & 1 & 他人にわかる & 1 & 垵返り & 5 & & \\
\hline 7.黄㾝 (2) & & 両麻痶 & 2 & 家族のみ & 2 & 移動不可 & 6 & & \\
\hline 症状 $(-)$ & 1 & 三肢麻瘦 & 3 & Yes, No程度 & 3 & 33.経減的自立 & & & \\
\hline 症状 $(+)$ & 2 & 四肢麻㾝 & 4 & まったくなし & 4 & 自立 & 1 & & \\
\hline 8. 新生児痤受 & & 片麻疸 & 5 & 26. 独步 現在 & & 一部収入あり & 2 & & \\
\hline 発作 $(-)$ & 1 & 18.10 (3歳) & & 可 & 1 & 不可 & 3 & & \\
\hline 発作 $(+)$ & 2 & $80 \leqq$ & 1 & 不可 & 2 & 34.手術回数 & & & \\
\hline 9.唃乳力 & & $50 \leqq<80$ & 2 & 27.实用移動伥 & & O回 & 1 & & \\
\hline 良 & 1 & $25 \leqq<50$ & 3 & 可 & 1 & 1回 & 2 & & \\
\hline 不良 & 2 & $<25$ & 4 & 不可 & 2 & 2 回以上 & 3 & & \\
\hline
\end{tabular}

\begin{tabular}{|c|c|c|c|c|c|c|c|}
\hline 41 Moro消失 & 0 & 1 & 2 & ? & $A$ & 1 & 201 \\
\hline & & & & & 4 & 4 & 4は36M〜bYと古の後残存も含む \\
\hline 42.ATNR消失 & 0 & 1 & 2 & 3 & 4 & 4 & 4は36M〜5Yと关の後残存も含む \\
\hline 43.时立て宪成 & 0 & 1 & 2 & 3 & 4 & 4 & 4は36M〜5Yと炎の後未完成も含む \\
\hline 44.首座り完成 & 0 & 1 & 2 & 3 & 4 & 4 & 4は36M〜 5Yどをの後未完成も含む \\
\hline 45.坐位 & 0 & 1 & 2 & 3 & 4 & 5 & 6不可 \\
\hline 46.四つ逜い & 0 & ナシ & 1 & 2 & 3 & 4 & 5不可 \\
\hline 47. 时通い & 0 & 1 & 2 & 3 & 4 & 5 & 6不可 \\
\hline 48.亳返り & 0 & 1 & 2 & 3 & 4 & 5 & 6不可 \\
\hline 49.独步 & ナシ & ナシ & ナシ & 3 & 4 & 5 & 0，1，2はサンプルなし，6不可 \\
\hline 50. 発搳時期 & 0 & ナシ & 1 & 2 & 3 & 4 & 5不可 \\
\hline
\end{tabular}


た. (2)移動関連項目の予後予測を検討するために ロジスチック回帰分析を行った。

\section{3. 結 果}

群間の差を $\chi^{2}$ 検定.

1）新生児黄疸が重症であった例の治療法につ いての検討

C 群には 29 例が存在したが, この内, 処置 (一) が 25 例, 交換輸血は 4 例, 光線療法は 0 例 施行であった。B群は 22 例で, 処置 (一) 9 例, 交換輸血 8 例, 光線療法 5 例であった. A 群は 37 例で, 処置 $(一) 6$ 例, 光線療法が 26 例と最も 多く見られ, 交換輸血は 5 例であった. 治療法が 処置 (一) から交換輸血, 光線療法へと変化したこ とを示していた～$\chi^{2}$ 検定では $1 \%$ で有意であっ た.

2）新生児重症黄疸の症状（重症黄疸, 落陽現 象, 上方視麻痺, 過敏なモロー反応, 難聴, 唃歯

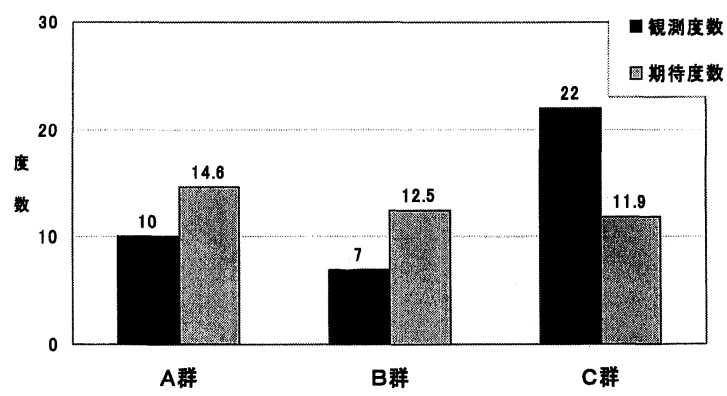

図 1 新生児重症黄疸の症状（ $\chi^{2}$ 検定：1\%有意）
など）の出現に関する検討

図 1 は新生児重症黄疸の症状が存在している例 数を示している.いずれの群においても統計的処 理からの算出される期待度数と観測度数, すなわ ち実際の症例数との差が著明であった．各群と黄 疸の症状とは独立であるという仮説は $\chi^{2}$ 検定で 1\%で棄却されることになり, 各群特有の症状と 考えられた。

$\mathrm{C}$ 群で新生児重症黄疸の症状が存在するのは 22 例で, この結果としてアテトーゼ型が多く出 現すると予想され，図 2 がそれを示している.

3）アテトーゼ型の発生頻度に関する検討

図 2 の下段のアテトーゼの有無を見るとC 群 では期待度数 36.3 に比し観測度数は 52 であり, この約半数は重症新生児黄疸であったが処置 $(一)$ （上記 1)参照）の結果と考えられる．A 群では期 待度数 44.4, 観測度数 28 であり, C 群と著明な 差が見られた。この中でもやはり重症新生児黄疸 によると思われる例が図 1 に示すように 10 例近 く存在した。すなわち C 群にアテトーゼの存在 が著明に多く, 痙直性の存在は逆の関係があり, いずれも $\chi^{2}$ 検定で各群との関連が独立であると いう仮説が $1 \%$ で棄却され，関連があると考えら れる.その原因は新生児重症黄疸の治療法がその 間に変化したことであると思われる。

4）麻痺領域に関する検討

図 3 は麻痺領域に関するものである．いずれの

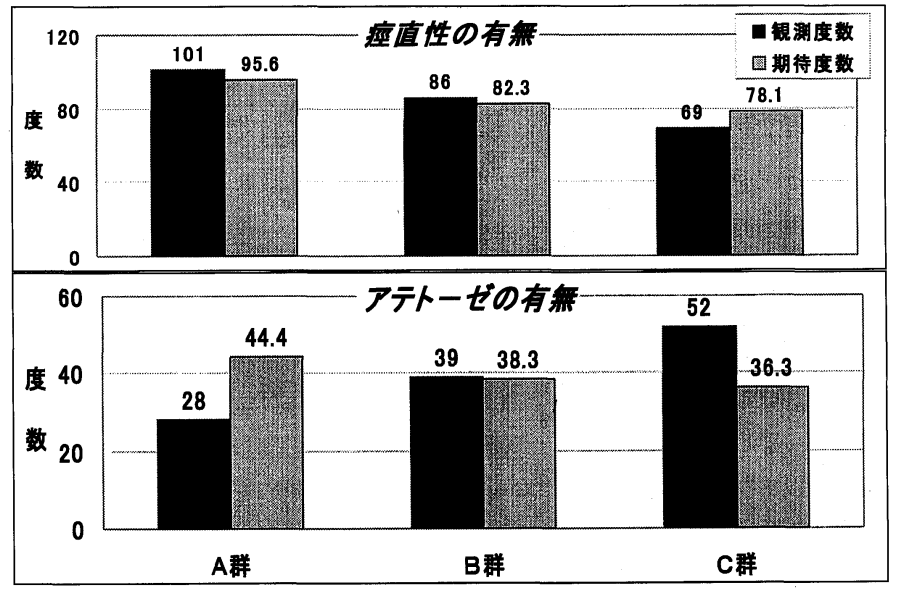

図 2 痙直型とアテトーゼ型の発生数（ $\chi^{2}$ 検定：1\%有意 $)$ 


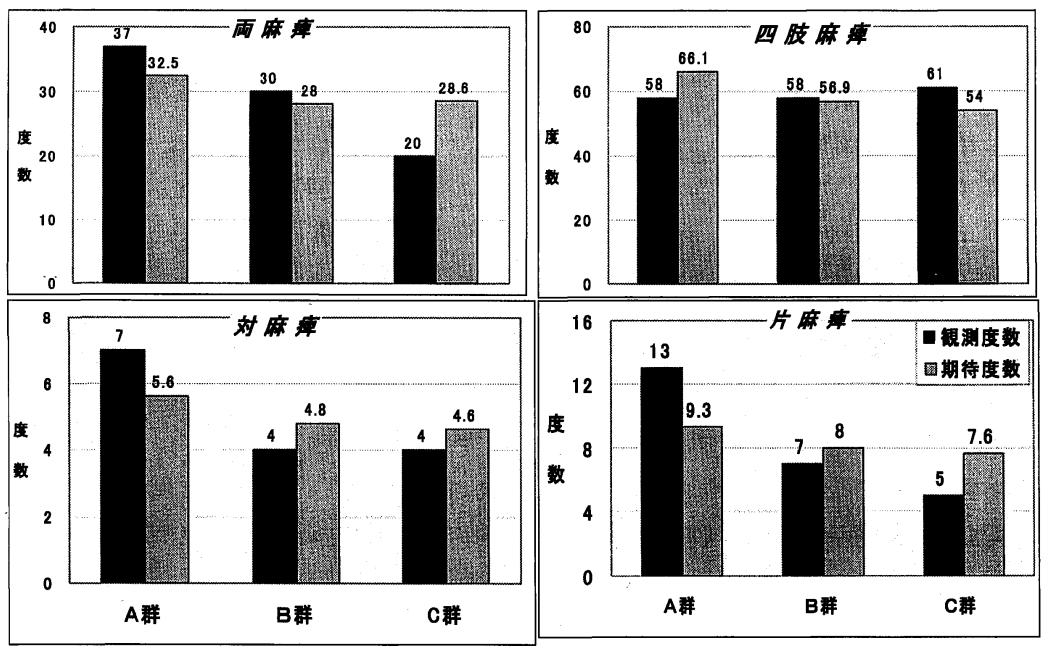

図 3 麻痺 領域
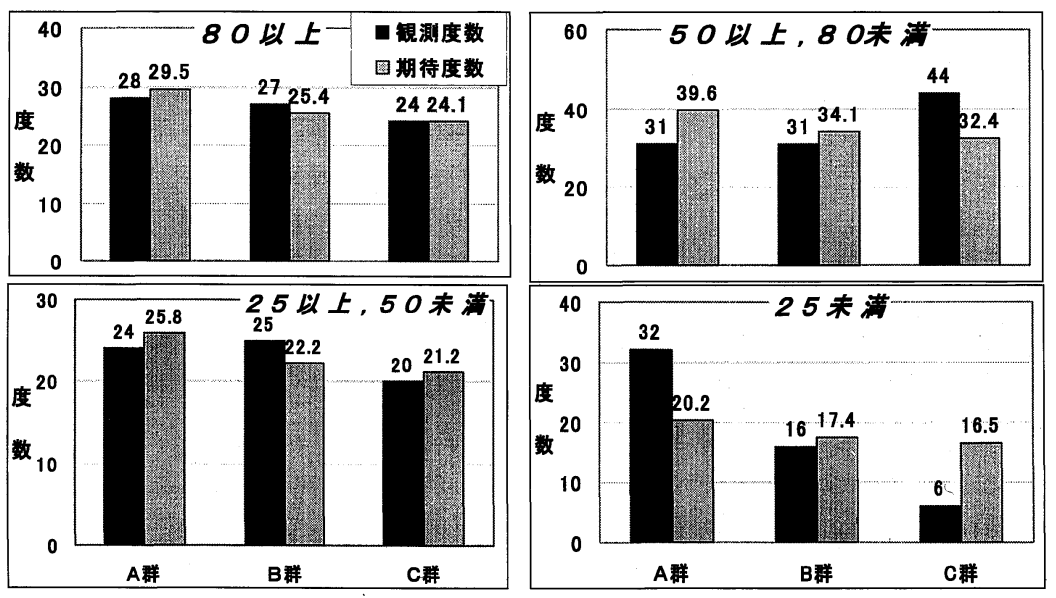

図 4 知的障害の発生数（IQ レベル）（ $\chi^{2}$ 検定：1\%有意）

麻痺領域においても期待度数と観測度数の差が少 なく，群間に差は見られない。またカテゴリー内 の観測度数, 期待度数とも 5 以下の所もあり, 参 考資料扱いとなる.

5）知的障害に関する検討

図 4 は知的障害に関するもので, 15 歳以上で の IQ 示している。IQ 25 以下に群間の差が著 明に見られる。C群では期待度数 16.5 に比し観 測度数は 6 である。一方 A 群では同様に 20.2 に 比し 32 と高値を示している。これも $\chi^{2}$ 検定では 1\%で独立性は棄却されてた。即ち C 群では知的 障害の強い例は有意に少なく, $\mathrm{A}$ 群では有意に
多いということになる。

6）重症心身障害の発生率に関する検討

重症心身障害の発生数と発生率は A 群で 40 例 $34.3 \%$ ，B群で 23 例 $23.2 \%$ ，そして C 群で 16 例 $17.0 \%$ であ，各群間での発生率に著明な差 が見られ，特に A 群で高値を示していた。 $\chi^{2}$ 検 定でも $5 \%$ で独立性の仮説は棄却され，年代間で 有意に差があると考えられた。

7）最高移動能力，独歩についても検討したが, 各群間に著明な差は見られなかった。

4. 考察ならびにまとめ

1）新生児重症黄㾝の治療法が進歩したので, 
アテトーゼ型が著明に減少したと考えられる，四 肢麻痺の発生率, 移動能力の程度には変化がなか った.

2）知的障害については，C $\rightarrow \mathrm{A}$ 群になると低 IQ 值を示す例が多くなっていた。

3）重症心身障害の発生率は A 群では高まって おり，この原因は麻痺が重度化したのではなく， 知的障害が重度になったためと考えられる。

4）低年齢の成人やこれから成人になる人に対 しては，知的障害が重度である可能性が高く，今 後はこれに対する対応が必要となってくると思わ れる。

5）またそれらが四肢麻痺を伴っていれば重症 心身障害となるので，重症心身障害に対する対応 も当然必要となると思われる，さらに今後の脳性 麻痺に対する対応として必要なことは，次に述べ るロジスチック回帰分析で明確にする。

\section{ロジスチック回帰分析}

\section{1. 対象・方法}

これまで述べて来た 308 例中，乳幼児期のデー 夕が揃っている 259 例を対象とした。これらにつ いて，移動の可否，独歩の可否，重症心身障害か 否かを幼児期までの調查項目から予測した。

また最後に，年長になるにつれて向上すべき移 動能力が，成長期を過ぎるとかえって能力低下を きたす例も見られるので，それについても予測し た.

\section{2. ロジスチック回帰分析とは3)}

図 5 はロジスチック回帰分析の理論について示

\begin{tabular}{|c|c|}
\hline $\begin{array}{l}\operatorname{logit} p(x)=\log \frac{p(x)}{1-p(x)} \\
p(x)=\frac{\exp \left(B_{1} x_{1}+B_{2}\right.}{1+\exp \left(B_{1} x_{1}+1\right.}\end{array}$ & $\begin{array}{l}=B_{1} x_{1}+B_{2} x_{2}+\cdots+B_{n} x_{n}+B_{0} \\
\frac{\left.x_{2}+\cdots+B_{n} x_{n}+B_{0}\right)}{\left.B_{2} x_{2}+\cdots+B_{n} x_{n}+B_{0}\right)}\end{array}$ \\
\hline 発症オッヅ $\frac{p(x)}{1-p(x)}$ & \begin{tabular}{|l|} 
発症する確率 $p(x)$ に対する \\
発症しない確率 1-p $(x)$ の比 \\
\end{tabular} \\
\hline
\end{tabular}

図 5 ロジスチック回帰分析 $0<p<0.5$ : 発症なし, $0.5<p<1$ : 発症ありと予測する. logit $p(x)$ は $p(x)$ のロジット（logit）または対数オッヅ （log odd）と呼ばれる.
したものである. 説明変数 $\left(x_{1}, x_{2}, x_{3}, \cdots, x_{n}\right)$ が 観測されたという条件下で, 疾病, 症状が出現 する確率を $p(x)$ とし，それと出現しない確率 1 - $p(x)$ の比を求める。これを発症オッヅ（incidence odds）という。これの対数をとったもの を $p(x)$ のロジット（logit）という。これを調査 項目を説明変数とする重回帰式で表わすとロジス チック回帰モデル (logistic regression model) ができる．最上段の数式がこれを示している。そ れを変形したものをその下段に示すが，同一の意 味を持っている。

対象となる個体の中には，種々の説明変数の力 テゴリー組合せが存在するが，この相異なる組合 せのパターンを抽出し，それを区別するために番 号を付ける。これをプロファイル（profile）と呼 ぶ. 同一のプロファイルの中では説明変数のカテ ゴリーの組合せパターンはその定義からして同一 であるが，疾病や症状が出現したかどうかは個及 別々である．そこでこの同一プロファイルの中で の症状等の出現した数が観測数として算出され る.その観測数がでる確率は, 確率 $p(x)$ の二項 分布に従っていると考える.

このようにして，各プロファイルごとに出現す る観測数が算出されるので，それぞれの観測数の 出現確率が $p(x)$ の関数として現すことができ る.ところが $p(x)$ はこれから決めようとしてい る係数 $\mathrm{B}\left(\mathrm{B}_{1}, \mathrm{~B}_{2}, \cdots \mathrm{B}_{n}, \mathrm{~B}_{0}\right.$ は定数 $)$ の変数とも 考えられので， $\mathrm{B}$ を適切に決めれば，プロファイ ルごとに決まってくる $p(x)$ も適切に決まってく る.この B を決定するために最尤法が用いられ る. 通常の回帰分析の場合は最小 2 乗法が用いら れるので，処理の仕方は異なることになる.

B が決まると，各症例ごとに，観測，実測した データを回帰式に代入すると， $p(x)$ のロジット， 続いて $p(x)$ が計算される. $p(x)$ が 0.5 より小で あれば発症なし，0.5より大であれば発症ありと 予測を定義する. $p(x)$ は式から 0 から 1 までの 值をとり確率変数として適切であることが分か $る^{11}$. 


\section{3. 結 果}

1）移動が可能か否かを予測（図 6)

ロジスチック回帰式により計算された より大であれば移動が可能と決め, 各症例につい て当てはめると，正答率は $95.8 \%$ となた，意 味のある説明変数は, 时立て完成時期, 脊柱側弯 の有無, 摂食機能であった。説明変数の選択基準 は，有意確率 5\%前後以下を目安とする。これま で発表して来た数量化 2 類の分析では, 正答率は $94.2 \%$ であり，ロジスチック回帰分析の方が幾分 予測は良好と思われる。下段に示してある Hosemer \& Lemeshow 検定は, ロジスチック回 帰分析により示されたモデル值が実測值とどの程 度隔たりがあるかを $\chi^{2}$ 検定したもので, 有意確 率 0.399 であり，大きく隔たりがあるとは言えな い.
2）独歩が可能か否かを予測（図 7）

前項と同様の方法により独歩が可能か否かを子 測した. 正答率は $86.9 \%$. 意味のある説明変数 は首すわり完成時期, 四つ這い完成時期, 幼児期 $\mathrm{IQ}$, 麻痺領域であった. 数量化 2 類の分析結果 では正答率 $84.2 \%$ であった。 意味ある説明変数 は殆ど変わりがなかった。

\section{3）重症心身障害の有無を予測（図 8)}

正答率は $86.1 \%$. 意味のある説明変数は 3 歳 までの攝食状況, 首すわり完成時期, 幼児期の痤 攣発作, 股関節脱臼, 脊柱側弯の有無であった. 数量化 2 類による分析結果は正答率 $86.4 \%$ あ゙あ った. 説明変数にも大きな差異は見られなかっ た.

4）移動能力低下を予測（図 9)

正答率は $86.2 \%$ で, 意味ある説明変数は最大

\begin{tabular}{|c|c|c|c|c|c|c|}
\hline $\begin{array}{l}\text { 説明変数 } \\
\text { 有意確率 }\end{array}$ & $\begin{array}{l}\text { 肘立て } \\
\text { 完成時期 } \\
\mathbf{0 . 0 0 0 0}\end{array}$ & & $\begin{array}{l}\text { 答柱側弯 } \\
0.001\end{array}$ & & $\begin{array}{c}\text { 摄食機能 } \\
0.002\end{array}$ & $\begin{array}{l}\text { 定数 } \\
0.000\end{array}$ \\
\hline $\log \frac{p(x)}{1-p(x)}$ & $\left(\begin{array}{c}-4.199 \\
-1.455 \\
-2.483 \\
-3.035 \\
0\end{array}\right.$ & + & $\begin{array}{c}-2.783 \\
0.270 \\
0\end{array}$ & + & $\left(\begin{array}{c}-4.027 \\
-3.508 \\
0\end{array}\right.$ & +3.651 \\
\hline
\end{tabular}

Nagelkerke $R^{2}: 0.841$

Hosmer \& Lemeshow 検定 : $\chi^{2}$ 值 6.218, 自由度 6 , 有意確率 0.399

○数量化 2 類分析 (偏相関係数の順) 正答率 : 94.2\%

説明変数 : 时立て完成時期, 寝返り完成時期, 側弯発生時期, 健康(幼児期), 首すわり完成時期

図 6 ロジスチック回帰分析により移動が可能か否かを予測（正 答率: $95.8 \%$ )

\begin{tabular}{|c|c|c|c|c|c|c|c|c|}
\hline $\begin{array}{l}\text { 説明変数 } \\
\text { 有意確率 }\end{array}$ & $\begin{array}{c}\text { 首すわり } \\
\text { 完成時期 } \\
0.010\end{array}$ & & $\begin{array}{c}\text { 四つ這い } \\
\text { 開始時期 } \\
0.014\end{array}$ & & $\begin{array}{c}\text { 幼児期 IQ } \\
0.021\end{array}$ & & $\begin{array}{c}\text { 麻㾝領域 } \\
0.497\end{array}$ & $\begin{array}{l}\text { 定数 } \\
0.914\end{array}$ \\
\hline $\log \frac{p(x)}{1-p(x)}$ & $\left(\begin{array}{c}-1.208 \\
-1.958 \\
-2.756 \\
-1.111 \\
0\end{array}\right)$ & + & $\left(\begin{array}{c}-4.452 \\
-11.860 \\
-2.596 \\
-1.318 \\
-1.653 \\
0\end{array}\right.$ & + & $\left(\begin{array}{c}-16.548 \\
-15.198 \\
-15.168 \\
0\end{array}\right)$ & + & $\left(\begin{array}{c}3.390 \\
12.477 \\
12.627 \\
11.563 \\
0\end{array}\right.$ & +7.584 \\
\hline
\end{tabular}

Nagelkerke $R^{2}: 0.685$

Hosmer \& Lemeshow 検定 : $\chi^{2}$ 值 5.037, 自由度 7, 有意確率 0.655

○数量化 2 類分析 (偏相関係数の順) 正答率 : $84.2 \%$ 説明変数 : 麻㾝領域, 首すわり時期, 四つ這い完成時期, I Q (幼児期)

図 7 ロジスチック回帰分析により独歩が可能か否かを予測（正 答率: $86.9 \%$ ) 
中島雅之輔

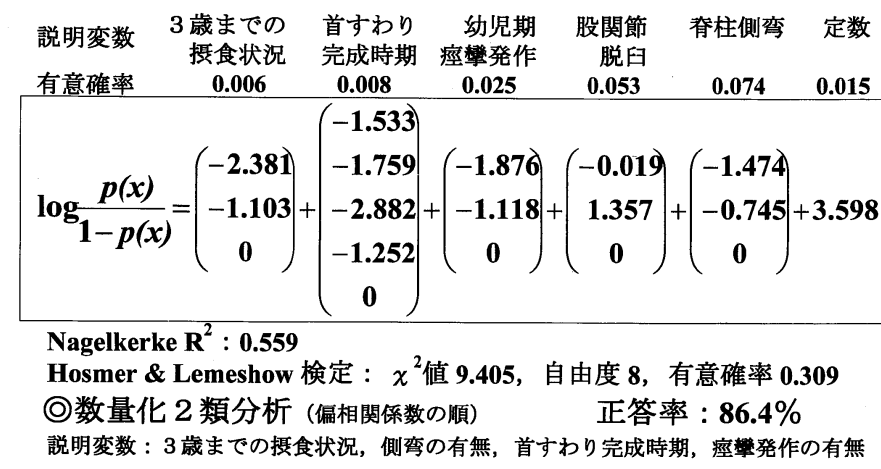

図 8 ロジスチック回帰分析により重症心身障害の有無の予測 (正答率： $86.1 \%$ )

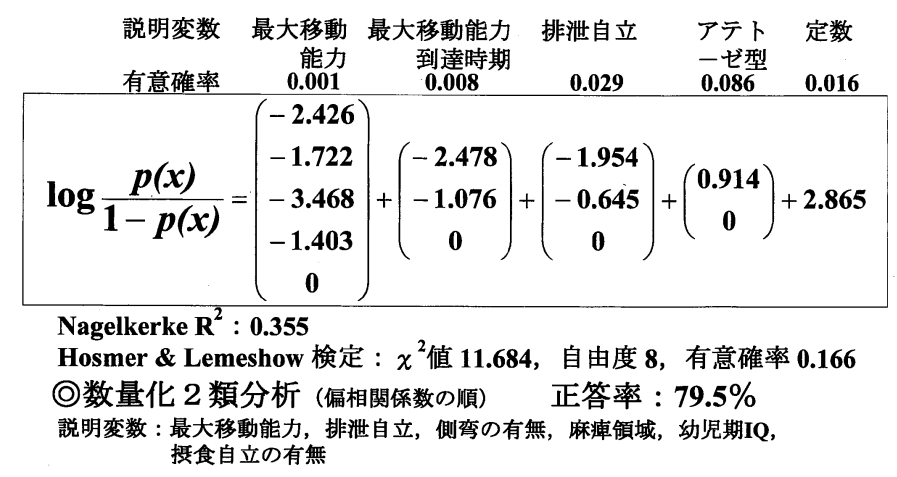

図9ロジスチック回帰分析により移動能力低下の予測（正答 率: $86.2 \%$ )

移動能力, 最大移動能力到達時期, 排泄自立, ア テトーゼ型の有無であった. 数量化 2 類では正答 率 79.5\%であった.ロジスチック回帰分析より 低値であった。

4. ロジスチック回帰分析に関するまとめ

1）ロジスチック回帰分析の中で重要な意味を 持つロジットの意味が直感的には分かりにくく, またこの理論も難しく理解しにくい.

2）正答率は全般に，これまで発表してきた数 量化 2 類の分析結果より良好である.またロジス チック回帰分析の方が国際的には通用する.

3）ロジスチック回帰分析では説明変数の有意 確率が算出され, 的確な説明変数の選択が可能で ある。

4）しかし，数量化 2 類の方がモデルに片寄り があった場合にも，バイアスが少なく，結果が妥 当であると言われている.

\section{全般を通じての考察ならびにまとめ}

1）能力低下の項ではアテトーゼ型が意味ある 説明変数として選択されたが，これはアテトーゼ 型であると能力低下が出現しにくいとの意味であ り，成人期の頸髄症の発症を考えると実際と異な るように思われる。しかし，これは成長期にも拘 縮が著明に出現せず，そのための能力低下が出現 しないと解するべきである，痙縮が著明な場合 は，成長期に能力低下をきたすことがあるのと対 比すべきである。

2）重症心身障害の発生予測では，3歳までの 摂食機能, 幼児期の痤攣発作は意味がある，との 結果がでたが，これは現在の臨床場面とよく一致 している.今後は前半の「各世代間の差異につい ての検討」で述べた重症心身障害には知的障害が 重要と言う観点に加えて，この 2 項目が重要とな 
ると思われる，健康な重症心身障害から，生命維 持機能に障害のある重症心身障害, すなわち超重 心が今後の重要な医療, 療育の問題点となると思 われる，大脳損傷による，運動障害，知的障害ば かりでなく，生命維持に必要な脳幹機能が侵され ているためと考えるのが適切であろう.

3）股関節脱臼, 脊柱側弯等高度の変形・拘縮 は重症心身障害と密接な関連があることは臨床的 に既に経験済みであるが，健康状態が悪いことを 考慮すると骨折に対しても十分な注意が必要があ ると考えられた。

4）ロジスチック回帰分析について：この中で 重要な意味を持つロジットの意味が直感的には分 かりにくく，この分析を採用しにくいという意見 が多いが，正答率は全般に，これまで発表してき た数量化 2 類の結果より良好であり，ロジスチッ ク回帰分析の方が国際的には通用すると言われて おり，今後多く利用されるようになると思われ る.

またロジスチック回帰分析では説明変数の有意 確率が算出され，適格な説明変数選択が可能であ る.しかし一方，数量化 2 類の方がモデルに片寄 りがあった場合にも，バイアスが少なく，結果が 妥当であるとの意見もある.

\section{文献}

1）中村純人ほか: 脳性麻痺の移動能力予後予測. 関節外 科 $2002 ; 21: 100-105$

2）横関 仁ほか: リハビリテーションに役立つ予後予 測. 脳性麻瘦にお斿る予後予測. J Clin Rehabil 1998; $7(4): 380-386$

3）丹後俊郎, 山岡和枝, 高木晴良: ロジスティック回帰 分析. SAS を利用した統計解析の実際. 朝倉書店, 東 京, 1996 